\title{
Microwave-Assisted Regioselective Suzuki Coupling of 2,4-Dichloropyrimidines with Aryl and Heteroaryl Boronic Acids
}

\author{
Ana Dolšak, Kristjan Mrgole and Matej Sova *(D) \\ Faculty of Pharmacy, University of Ljubljana, Aškerčeva 7, 1000 Ljubljana, Slovenia; \\ ana.dolsak@ffa.uni-lj.si (A.D.); mrgolekristjan@gmail.com (K.M.) \\ * Correspondence: matej.sova@ffa.uni-lj.si; Tel.: +386-1-4769556
}

check for updates

Citation: Dolšak, A.; Mrgole, K.; Sova, M. Microwave-Assisted Regioselective Suzuki Coupling of 2,4-Dichloropyrimidines with Aryl and Heteroaryl Boronic Acids. Catalysts 2021, 11, 439. https:// doi.org/10.3390/catal11040439

Academic Editor: Armando Carlone

Received: 5 March 2021

Accepted: 26 March 2021

Published: 30 March 2021

Publisher's Note: MDPI stays neutral with regard to jurisdictional claims in published maps and institutional affiliations.

Copyright: (c) 2021 by the authors. Licensee MDPI, Basel, Switzerland. This article is an open access article distributed under the terms and conditions of the Creative Commons Attribution (CC BY) license (https:/ / creativecommons.org/licenses/by/ $4.0 /)$.

\begin{abstract}
Suzuki coupling reaction has been often used for the preparation of a diverse set of substituted pyrimidines. In this study, the Suzuki coupling of 2,4-dichloropyrimidines with aryl and heteroaryl boronic acids was investigated. A thorough screening of reaction conditions and the use of microwave irradiation led to a very efficient and straightforward synthetic procedure providing C4substituted pyrimidines in good to excellent yields. Short reaction time ( $15 \mathrm{~min})$ and extremely low catalyst loading $(0.5 \mathrm{~mol} \%)$ are the main advantages of our tetrakis(triphenylphosphine)palladium $(0)$ catalyzed microwave-assisted procedure, which could be used for quick and low-cost regioselective preparation of substituted pyrimidine rings.
\end{abstract}

Keywords: cross-coupling; Suzuki; palladium; pyrimidines; synthesis; microwave-assisted

\section{Introduction}

Substituted pyrimidine rings as scaffolds are of great interest for medicinal chemists being a part of many biologically active compounds [1,2]. The pyrimidine moiety is present in many natural compounds [3] (e.g., nucleic acids, alkaloids, folic acid, etc.) as well as synthetic analogs and also in approved drugs on the market, e.g., anticancer [4-6], antiviral [4,7], antibacterial [8], antilipidemic [9], anti-inflammatory [3,10], and antimalarial agents (Figure 1). Large number of synthetic methods have been described for the preparation of pyrimidine-based compounds [11-16]. Cyclocondensation between guanidine, amidine or thiourea derivatives and 1,3-diketones or 1,3-diesters is the most classical method for the synthesis of the main pyrimidine core $[15,17]$, whereas one of the approaches to prepare substituted pyrimidine rings is via halogenated pyrimidines [18-20], which are greatly commercially available. The most common reactions involving various halogenated pyrimidines are cross-coupling reactions since pyrimidine ring is an electron-deficient aromatic system being far more reactive in comparison with analogous benzene halides [17,20]. Halogenated pyrimidines are thus very convenient substrates for substantial assortment of nucleophilic aromatic substitutions. Suzuki coupling of halogenated pyrimidines with boronic acids has been a commonly used approach for the preparation of a diverse set of substituted pyrimidines [20].

Polyhalogenated pyrimidines are commonly used substrates in cross-coupling reactions since each substituent could be added sequentially to a pyrimidine ring due to the intrinsic differences in reactivity at different positions [21-24]. In case of commonly used and commercially available 2,4-dichloropyrimidines, the regioselectivity preference in a Suzuki cross-coupling reaction was observed for C4-position due to the favored oxidative addition of palladium into the C4-chlorine bond [22,24,25]. Some anomalies have been observed, favoring C2 position over C4, mainly due to the steric reasons when additional substituents are present at other positions, i.e., C5 [24]. In the publication from Anderson and Handy in 2010, efficient synthesis of diarylated pyrimidines via regioselective double 
Suzuki coupling of 2,4-dichloropyrimidine was presented [21]. Similarly, the reaction occurred at the C4-position when 2,4-dichloropyrimidine or 2,4,6-trichloropyrimidine were coupled with alkenyl-boronic acids [26].<smiles>Cc1ccc(NC(=O)c2ccc(CN3CCN(C)CC3)cc2)cc1Nc1nccc(-c2cccnc2)n1</smiles>

Imatinib<smiles>CC(C)c1nc(N(C)S(C)(=O)=O)nc(-c2ccc(F)cc2)c1/C=C/C(O)C[C@H](O)CC(=O)O</smiles>

Rosuvastatin<smiles></smiles>

Zidovudine<smiles>Nc1cc(N2CCCCC2)nc(N)[n+]1[O-]</smiles>

Minoxidil<smiles>COc1cc(Cc2cnc(N)nc2N)cc(OC)c1OC</smiles>

Trimethoprim<smiles>CCc1nc(N)nc(N)c1-c1ccc(Cl)cc1</smiles>

Pyrimethamine

Figure 1. Representative drugs with pyrimidine moiety on the market: anticancer (e.g., imatinib [6]), antiviral (e.g., zidovudine [7]), antibacterial (e.g., trimethoprim [8]), antihyperlipidemic (e.g., rosuvastatin [9,27]), antihypertensive (e.g., minoxidil), and antimalarial (e.g., pyrimethamine).

The aim of our study was to develop a quick, efficient, and regioselective synthetic procedure for substituted pyrimidines at position C4 from readily available 2,4dichloropyrimidines via Suzuki coupling with a diverse set of aryl and heteroaryl boronic acids. The selection of appropriate solvents, catalysts, and reactions conditions (temperature, time) was systemically performed. Last, but not least, the optimal procedure was also transferred to a microwave reactor and further optimization (i.e., temperature, reaction time catalyst loading) was carried out.

\section{Results}

One of the most straightforward approaches to prepare substituted pyrimidines is via Suzuki coupling of halogenated pyrimidines with boronic acids $[20,21]$. There have been a variety of studies performed in order to propose the reaction mechanism underlaying the Suzuki-Miyaura coupling, consisting of several key steps. The initial pre-catalyst activation allows the formation of $\operatorname{Pd}(0)$ species. In the second step, during oxidative addition of aryl halide to the palladium center, the insertion of metal atom into the $C_{i p s o}$ and halide $(X)$ bond occurs and the complex [aryl-Pd(II)( $\left.\left.\mathrm{L}_{n}\right)-\mathrm{X}\right]$ forms, where $\mathrm{L}$ represents the potentially bound ligand to the palladium centre, with $n$ ranging from 1 to 4 [28]. Then the oxygencontaining nucleophile (either hydroxide from base followed by addition of boronic acid $\mathrm{RB}(\mathrm{OH})_{2}$, or boronate $\mathrm{RB}(\mathrm{OH})_{3}^{-}$) replaces the halide group at palladium, which is later followed by transmetalation leading to the formation of aryl-Pd(II) $\left(L_{n}\right)-R$ species. The final step includes reductive elimination of a product aryl-R with newly formed C-C bond, and regeneration of $\mathrm{Pd}(\mathrm{II})$ to $\mathrm{Pd}(0)$ [29]. In this study, Suzuki cross-coupling reaction between commercially available 2,4-dichloropyrimidine (1) and phenylboronic acid (2) was used as a model reaction to select appropriate catalyst, catalyst loading, solvent(s), and optimal 
reactions conditions (temperature, time). Our first attempt was to systemically screen the most common solvents used in Suzuki coupling reactions. Based on previous studies [21], tetrakis(triphenylphosphine)palladium $(0)\left(\mathrm{Pd}\left(\mathrm{PPh}_{3}\right)_{4}\right)$ along with potassium carbonate $\mathrm{K}_{2} \mathrm{CO}_{3}$ as a base was selected as the starting catalytic system (Scheme 1).<smiles>Clc1ccnc(Cl)n1</smiles>

1<smiles>OB(O)c1ccccc1</smiles>

2

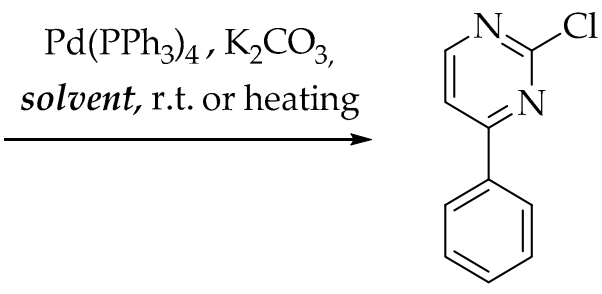

3<smiles>Clc1ccnc(-c2ccccc2)n1</smiles>

4

Scheme 1. Suzuki coupling of 2,4-dichloropyrimidine (1) with phenylboronic acid (2) as our model reaction.

A good selection of appropriate solvent for cross-coupling reactions is imperative. The screening of most common solvents for cross-coupling reactions (i.e., $\mathrm{H}_{2} \mathrm{O}, \mathrm{MeOH}, \mathrm{THF}$, DMF, 1,4-dioxane, isopropanol, ethylene glycol) was performed at a room temperature (r.t.) and higher temperatures $\left(60-100^{\circ} \mathrm{C}\right)$, with yields determined by LC-MS being obtained after $1 \mathrm{~h}, 2 \mathrm{~h}$, and $24 \mathrm{~h}$ (see Supporting Information, Table S1). The highest yields were obtained for less polar solvents, like isopropanol (64\%) and 1,4-dioxane (72\%), contrary to polar $\mathrm{H}_{2} \mathrm{O}, \mathrm{MeOH}, \mathrm{DMF}$, and ethylene glycol, which corresponds to the observation made by Miyaura about $\mathrm{Pd}\left(\mathrm{PPh}_{3}\right)_{4}$ [30]. The choice of solvent (therefore its boiling point) defines the maximum operating temperature [31]. On the set of less polar solvents THF, isopropanol, and 1,4-dioxane with boiling points of $66^{\circ} \mathrm{C}, 83^{\circ} \mathrm{C}$, and $101{ }^{\circ} \mathrm{C}$, respectively, we confirmed that higher temperatures vastly improve the yield of reaction due to the high activation barriers reagents need to overcome for successful coupling. The $\mathrm{C} 2$ side product was formed in less than $8 \%$, which is consistent with the literature reports [24].

We decided to repeat the reaction in four best solvents (i.e., THF, DMF, 1,4-dioxane and isopropanol) and isolate the pure product 3 by column chromatography. The isolated yields are presented in Table 1 . The highest yield of $71 \%$ was obtained for non-polar 1,4-dioxane, which has been reported to complement $\mathrm{Pd}\left(\mathrm{PPh}_{3}\right)_{4}$ [30], thus we decided to proceed with further optimization in this solvent.

Table 1. The isolated yield of product 3 after Suzuki coupling of 2,4-dichloropyrimidine (1) with phenylboronic acid (2) in four selected solvents.

\begin{tabular}{cccc}
\hline Entry & Solvent & Temperature $\left({ }^{\circ} \mathbf{C}\right)$ & Yield $(\mathbf{\%}) \mathbf{~}^{\mathbf{1 , 2}}$ \\
\hline 1 & THF & 60 & 38 \\
2 & DMF & 100 & 31 \\
3 & 1,4-dioxane & 100 & 71 \\
4 & isopropanol & 80 & 52
\end{tabular}

${ }^{1}$ Reaction conditions: 1 (149 mg, $\left.1.0 \mathrm{mmol}\right)$, solvent $(7 \mathrm{~mL}), \mathrm{K}_{2} \mathrm{CO}_{3}(415 \mathrm{mg}, 3.0 \mathrm{mmol}), 2(122 \mathrm{mg}, 1.0 \mathrm{mmol})$ $\mathrm{Pd}\left(\mathrm{PPh}_{3}\right)_{4}(58 \mathrm{mg}, 0.05 \mathrm{mmol}, 5 \mathrm{~mol} \%)$, heating $\left(60,80\right.$ or $\left.100{ }^{\circ} \mathrm{C}\right), 24 \mathrm{~h} .{ }^{2}$ Isolated yield of 3 after extraction and column chromatography.

In a continuation of our study, we screened the most common commercially available palladium catalysts for this type of reaction. Tris(dibenzylideneacetone)palladium(0) $\left(\mathrm{Pd}_{2} \mathrm{dba}_{3}\right)$ was not efficient for this type of reaction as has already been observed [32,33], whereas as an adduct with chloroform $\left(\mathrm{Pd}_{2} \mathrm{dba}_{3} \cdot \mathrm{CHCl}_{3}\right)$ and together with tri-tertbutylphosphonium tetrafluoroborate (TTBP $\cdot \mathrm{HBF}_{4}$ ) as a ligand it gave $35 \%$ and $23 \%$ yield, respectively (Table 2, entries 1-3). With bis(triphenylphosphine)palladium(II) chloride $\left(\mathrm{PdCl}_{2}\left(\mathrm{PPh}_{3}\right)_{2}\right)$ similarly low yield of $36 \%$ was achieved (Table 2, entry 4$)$. Further we screened palladium(II) acetate $\left(\mathrm{Pd}(\mathrm{OAc})_{2}\right)$ in combination with three different ligands, 
namely tricyclohexylphosphine $\left(\mathrm{PCy}_{3}\right)$, triphenylphosphine $\left(\mathrm{PPh}_{3}\right)$, and triphenylphosphine bound of divinylbenzene ( $\mathrm{PPh}_{3}$ on DVB), with yields not significantly improved (Table 2, entries 5-7). According to the mechanism proposed, Pd(II) pre-catalysts have to be reduced to $\operatorname{Pd}(0)$ prior to their involvement in oxidative addition. It has been reported that trimeric $\mathrm{Pd}(\mathrm{OAc})_{2}$ is more susceptible to reduction in its monomeric form, whose formation has been shown to be proportional to the dipole moment of the solvent used [34]. In our screening, 1,4-dioxane with low dipole moment of only $0.45 \mathrm{D}$ was used, which might be the reason for lower yields of Suzuki coupling with $\mathrm{Pd}(\mathrm{OAc})_{2}$. Solid-supported catalysts represent an attractive approach in the field of green organic chemistry, since they can often be recycled without loss of activity, in addition to the products and solution waste remaining free from metal contamination [35]. Despite several successful applications in Suzuki-Miyaura coupling [36-38], no product was formed when palladium on multiwall carbon nanotubes was used as a catalyst. Additionally, the screening was performed on a set of classic and solid-supported catalysts $\mathrm{Pd}(\mathrm{OAc})_{2}$ with $\mathrm{PPh}_{3}$ and $\mathrm{Pd}(\mathrm{OAc})_{2}$ with $\mathrm{PPh}_{3}$ on DVB, respectively, with the latter exhibiting inferior catalytic ability and yield in our model reaction. Only one catalyst $\left(\left[1,1^{\prime}\right.\right.$-Bis(diphenylphosphino)ferrocene $]$ dichloropalladium(II), in complex with dichloromethane $\left(\mathrm{Pd}(\mathrm{dppf}) \mathrm{Cl}_{2} \cdot \mathrm{CH}_{2} \mathrm{Cl}_{2}\right.$ ) led to a higher yield of $70 \%$ (Table 2, entry 8), which could be due to its ability (i.e., wide bite-angle P-Pd-P) of driving very effective reductive elimination [39]. Since there was no improvement compared to $\mathrm{Pd}\left(\mathrm{PPh}_{3}\right)_{4}$ (Table 2, entry 9), all further reactions were performed with $\mathrm{Pd}\left(\mathrm{PPh}_{3}\right)_{4}$.

Table 2. Catalyst screening for Suzuki coupling of 1 with 2.

\begin{tabular}{|c|c|c|c|c|c|}
\hline \multirow{2}{*}{ Entry } & \multirow{2}{*}{ Catalyst (ligand) } & \multicolumn{3}{|c|}{ Yield $(\%)^{1,2}$} & \multirow{2}{*}{ Selectivity Ratio $3: 4^{3}$} \\
\hline & & $1 \mathrm{~h}$ & $2 \mathrm{~h}$ & $24 \mathrm{~h}$ & \\
\hline 1 & $\mathrm{Pd}_{2} \mathrm{dba}_{3}$ & 0 & 0 & 2 & / \\
\hline 2 & $\mathrm{Pd}_{2} \mathrm{dba}_{3} \cdot \mathrm{CHCl}_{3}$ & 15 & 21 & 35 & 5 \\
\hline 3 & $\mathrm{Pd}_{2} \mathrm{dba}_{3}\left(T T B P \cdot H B F_{4}\right)$ & 10 & 11 & 23 & 11.5 \\
\hline 4 & $\mathrm{PdCl}_{2}\left(\mathrm{PPh}_{3}\right)_{2}$ & 12 & 17 & 36 & 4.5 \\
\hline 5 & $\mathrm{Pd}(\mathrm{OAc})_{2}\left(P C y_{3}\right)_{2}$ & 10 & 12 & 26 & 13 \\
\hline 6 & $\mathrm{Pd}(\mathrm{OAc})_{2}\left(P P h_{3}\right)_{2}$ & 28 & 37 & 46 & 10 \\
\hline 7 & $\mathrm{Pd}(\mathrm{OAc})_{2}\left(P P h_{3} \text { on } \mathrm{DVB}\right)_{2}$ & 15 & 22 & 27 & 7 \\
\hline 8 & $\mathrm{Pd}(\mathrm{dppf}) \mathrm{Cl}_{2} \cdot \mathrm{CH}_{2} \mathrm{Cl}_{2}$ & 26 & 38 & $70(63)^{4}$ & 10 \\
\hline 9 & $\mathrm{Pd}\left(\mathrm{PPh}_{3}\right)_{4}$ & 29 & 41 & $72(71)^{4}$ & 9 \\
\hline
\end{tabular}

${ }^{1}$ Reaction conditions: 1 (75 mg, $\left.0.50 \mathrm{mmol}\right), 1,4$-dioxane $(3.5 \mathrm{~mL}), \mathrm{K}_{2} \mathrm{CO}_{3}(207 \mathrm{mg}, 1.50 \mathrm{mmol}), 2(61 \mathrm{mg}$ $0.50 \mathrm{mmol}), 5 \mathrm{~mol} \%$ of a catalyst $(10 \mathrm{~mol} \%$ of a ligand $), 100{ }^{\circ} \mathrm{C}, 1-24 \mathrm{~h} .{ }^{2}$ Determined by LC-MS. ${ }^{3}$ Determined by LC-MS after $24 \mathrm{~h}$ reaction time. ${ }^{4}$ Isolated yield of 3 after extraction and column chromatography.

One parameter was screened additionally after selection of the appropriate catalyst, i.e., temperature (see Supporting Information, Table S2). Lowering the temperature significantly reduced the yield, thus all further reactions were performed at $100{ }^{\circ} \mathrm{C}$.

After the first optimization process, we decided to further upgrade the reaction procedure with the aim to improve the yields and shorten the reaction time by performing it in a microwave reactor. We started with the solvent scan, where $\mathrm{H}_{2} \mathrm{O}$ due to favorable dielectric constant for microwave heating was added in different proportions to THF or 1,4-dioxane. With this experiment, where total solvent volume was $6 \mathrm{~mL}$, we tried to find the optimal solvent ratio $(v / v)$ to obtain the highest yield of $\mathbf{3}$ and as little as possible of any side products (Table 3). Generally, the yield of 3 was improved, when $\mathrm{H}_{2} \mathrm{O}$ was present in the reaction mixture, with the peak at solvent ratio 1:1 or 2:1 in the favor of non-polar solvent for THF and 1,4-dioxane, respectively (Table 3, entries 1 and 8). In addition to possessing dipole moment, the presence of water is also beneficial due to increased amount of hydrophilic boronates $\mathrm{RB}(\mathrm{OH})_{3}{ }^{-}$[31]. Overall, solvent mixture of 1,4-dioxane and $\mathrm{H}_{2} \mathrm{O}$ in ratio $2: 1$ appeared to be the most optimal, with $80 \%$ yield. 
Table 3. Solvent mixture screening for Suzuki coupling of $\mathbf{1}$ with 2.

\begin{tabular}{ccccc}
\hline Entry & $\begin{array}{c}\text { Non-Polar } \\
\text { Solvent }\end{array}$ & Polar Solvent & $\begin{array}{c}\text { Ratio Non-Polar vs. Polar } \\
\text { Solvent (v/v) }\end{array}$ & Yield (\%) $\mathbf{1 , 2}$ \\
\hline 1 & $\mathrm{THF}$ & $\mathrm{H}_{2} \mathrm{O}$ & $1: 1$ & 53 \\
2 & $\mathrm{THF}$ & $\mathrm{H}_{2} \mathrm{O}$ & $2: 1$ & 23 \\
3 & $\mathrm{THF}$ & $\mathrm{H}_{2} \mathrm{O}$ & $3: 1$ & 20 \\
4 & $\mathrm{THF}$ & $\mathrm{H}_{2} \mathrm{O}$ & $5: 1$ & 13 \\
5 & $\mathrm{THF}$ & $\mathrm{H}_{2} \mathrm{O}$ & $9: 1$ & 14 \\
6 & $\mathrm{THF}$ & $/$ & $/$ & 21 \\
\hline 7 & 1,4-dioxane & $\mathrm{H}_{2} \mathrm{O}$ & $1: 1$ & 45 \\
8 & 1,4-dioxane & $\mathrm{H}_{2} \mathrm{O}$ & $2: 1$ & 80 \\
9 & 1,4-dioxane & $\mathrm{H}_{2} \mathrm{O}$ & $3: 1$ & 59 \\
10 & 1,4-dioxane & $\mathrm{H}_{2} \mathrm{O}$ & $5: 1$ & 58 \\
11 & 1,4-dioxane & $\mathrm{H}_{2} \mathrm{O}$ & $9: 1$ & 24 \\
12 & 1,4-dioxane & $/$ & $/$ & 21 \\
\hline
\end{tabular}

${ }^{1}$ Reaction conditions: 1 (75 mg, $\left.0.50 \mathrm{mmol}\right)$, solvent(s) $(6 \mathrm{~mL}), \mathrm{K}_{2} \mathrm{CO}_{3}(207 \mathrm{mg}, 1.50 \mathrm{mmol}), 2(61 \mathrm{mg}, 0.50 \mathrm{mmol})$, $\mathrm{Pd}\left(\mathrm{PPh}_{3}\right)_{4}(17.3 \mathrm{mg}, 0.015 \mathrm{mmol}, 3 \mathrm{~mol} \%), \mathrm{MW}, 100{ }^{\circ} \mathrm{C}, 20 \mathrm{~min} .{ }^{2}$ Yield for 3 , determined by LC-MS.

A scan of minimal solvent volume of 1,4-dioxane/ $\mathrm{H}_{2} \mathrm{O}$ (2:1) was performed (see Supporting Information, Table S3). Initial total volume of $6 \mathrm{~mL}$ in addition to $4.5 \mathrm{~mL}$ were found as the most suitable, while the yield significantly decreased when smaller solvent volumes were used. All further experiments were performed in total volume of $6 \mathrm{~mL}$. Microwave-assisted reaction conditions, i.e., temperature and time, were further evaluated. First, the reaction mixture was subjected to temperature scan ranging from $60^{\circ} \mathrm{C}$ to $140{ }^{\circ} \mathrm{C}$ with the interval of $20^{\circ} \mathrm{C}$ (Table 4). The temperature of $100{ }^{\circ} \mathrm{C}$ appeared to be the most optimal leading to $80 \%$ yield. Higher temperatures (i.e., $120^{\circ} \mathrm{C}$ and $140{ }^{\circ} \mathrm{C}$, entries 7 and 10 , respectively) did not improve the yield, since the side product 2,4-diphenylpyrimidine was formed. Additionally, time of the reaction was monitored for temperatures equal or above $100{ }^{\circ} \mathrm{C}$. Reaction time of $15 \mathrm{~min}$ at $100^{\circ} \mathrm{C}$ (yield $81 \%$, entry 4) was found as equally efficient as $20 \mathrm{~min}$. Therefore, these conditions were used for all further reactions.

Table 4. Temperature and time screening for Suzuki coupling of $\mathbf{1}$ with $\mathbf{2}$.

\begin{tabular}{cccc}
\hline Entry & Temperature $\left[{ }^{\circ} \mathbf{C}\right]$ & Time $[\mathbf{m i n}]$ & Yield $\mathbf{( \% )} \mathbf{~} \mathbf{1 , 2}^{(20}$ \\
\hline 1 & 60 & 20 & 12 \\
2 & 80 & 20 & 60 \\
3 & 100 & 20 & 80 \\
4 & 100 & 15 & 81 \\
5 & 100 & 10 & 59 \\
6 & 100 & 5 & 46 \\
7 & 120 & 20 & 60 \\
8 & 120 & 10 & 61 \\
9 & 120 & 5 & 66 \\
10 & 140 & 20 & 56 \\
11 & 140 & 5 & 61 \\
\hline
\end{tabular}

${ }^{1}$ Reaction conditions: 1 (75 mg, $\left.0.50 \mathrm{mmol}\right), 1$,4-dioxane $(4 \mathrm{~mL}), \mathrm{H}_{2} \mathrm{O}(2 \mathrm{~mL}), \mathrm{K}_{2} \mathrm{CO}_{3}(207 \mathrm{mg}, 1.50 \mathrm{mmol}), 2$ (61 mg, $0.50 \mathrm{mmol}), \mathrm{Pd}\left(\mathrm{PPh}_{3}\right)_{4}(17.3 \mathrm{mg}, 0.015 \mathrm{mmol}, 3 \mathrm{~mol} \%)$, MW, temperature, time. ${ }^{2}$ Yield for 3, determined by LC-MS.

To investigate the optimal amount of catalyst needed for the microwave-assisted Suzuki coupling, we performed the scan of catalyst loading, ranging from $5 \mathrm{~mol} \%$ to 0.05 $\mathrm{mol} \%$. Contrary to the results from the experiments, performed in a flask, the minimal amount of catalyst needed for microwave-assisted reaction was only $0.5 \mathrm{~mol} \%$ (Table 5), with lower amounts shown to be insufficient for all starting material to react. 
Table 5. Screening of $\mathrm{Pd}\left(\mathrm{PPh}_{3}\right)_{4}$ loading for Suzuki coupling of $\mathbf{1}$ with 2.

\begin{tabular}{ccc}
\hline Entry & Catalyst loading $\mathbf{( m o l} \mathbf{\%})$ & Yield $_{\mathbf{~ ( \% )}} \mathbf{1 , 2}$ \\
\hline 1 & 5 & 68 \\
2 & 3 & 65 \\
3 & 2 & 59 \\
4 & 1 & 62 \\
5 & 0.5 & 71 \\
6 & 0.2 & 61 \\
7 & 0.05 & 48 \\
8 & without catalyst & 0 \\
\hline
\end{tabular}

${ }^{1}$ Reaction conditions: 1 (75 mg, $\left.0.50 \mathrm{mmol}\right)$, 1,4-dioxane $(4 \mathrm{~mL}), \mathrm{H}_{2} \mathrm{O}(2 \mathrm{~mL}), \mathrm{K}_{2} \mathrm{CO}_{3}(207 \mathrm{mg}, 1.50 \mathrm{mmol})$, $2(61 \mathrm{mg}, 0.50 \mathrm{mmol}), \mathrm{Pd}\left(\mathrm{PPh}_{3}\right)_{4}(0-5 \mathrm{~mol} \%), \mathrm{MW}, 100{ }^{\circ} \mathrm{C}, 15 \mathrm{~min} .{ }^{2}$ Determined by LC-MS.

A scale-up of the model reaction on proposed reaction conditions has further been performed. The reaction was performed on $4.0 \mathrm{mmol}$ scale of starting reagents, with obtained yield of 3 being 53\%, and 30\% of 1 still remaining unreacted in the reaction mixture. Therefore, we prolonged the microwave reaction time for $5 \mathrm{~min}$ to $20 \mathrm{~min}$ and improved the yield of 3 to $74 \%$, with only $19 \%$ of 1 still being present in the reaction mixture. Taken together, we can conclude that our microwave-assisted procedure is also suitable for production of aryl pyrimidines on larger scales.

With the optimal conditions being determined, the scope of several aryl and heteroaryl boronic acids was investigated (Table 6). On the series of methoxyphenyl boronic acids, different substituent positions on the aromatic ring were evaluated (products 26, 27, and 28); however, no significant effect on the yield and selectivity was found between ortho, meta or para position of a methoxy group. Therefore, we preferentially focused on meta-substituents in the following reactions. Overall, the main product was consistently the 4-substituted 2-chloropyrimidine, with little or usually none of 2-substituted 4-chloropyrimidine being formed during the reaction. Several different substituents were screened for and it was noticed that yields of phenylboronic acids with electron-withdrawing groups on meta position (30 to 33) were rather high and comparable to the model reaction (3). Other boronic acids with carboxylic and electron-donating groups (i.e., amino group) led to lower yields. As expected, the naphthyl boronic acid (product 37) displayed similar yield to our model reaction with phenylboronic acid 2 (3).

Some heteroaryl boronic acids were also screened, with the reaction being selective and successful for both furanylboronic acids (38 and 39) with comparable yield. However, the coupling of 2,4-dichloropyrimidine with thiophen-2-boronic acid failed due to the sulphur poisoning of the palladium catalyst [40]. Furthermore, in case of pyridinylboronic acids, the reaction was also unsuccessful.

The microwave-assisted procedure for formation of 4-phenylpyrimidines was further screened on the series of differently substituted 2,4-dihalogenopyrimidines (Table 7). Despite chloroarenes being generally inert to oxidative addition, some electron-deficient heteroaryl chlorides (i.e., 2,4-dichloropyrimidines) are enough reactive for successful crosscoupling reactions [30]. Interestingly, the coupling of 2 with 2,4-dibromopyridine (19) did not offer improved yield (product 40) and the formation of a side product 2-phenyl4-bromopyrimidine was neither increased. The substitutions on the position 6 of 2,4dichloropyrimidine (19-25) with electron-withdrawing and electron-donating groups did not significantly affect the yield of the reaction (e.g., 43 and 45 with electron donor substituent versus 42 with electron withdrawing group), with the exception of 41 and $\mathbf{4 6}$, which led to lower yields of $27 \%$ and $54 \%$, respectively. Thus, we wanted to improve the yield of 41. The addition of $3 \mathrm{~mol} \%$ of $\mathrm{Pd}\left(\mathrm{PPh}_{3}\right)_{4}$ significantly improved the formation of 41, leading to $45 \%$ yield. Interestingly, the reaction of 2 with 2,4-dichloro-6-methoxypyrimidine (23) led to the production of both isomers 2-chloro-4-methoxy-6-phenylpyrimidine (44A) and 4-chloro-6-methoxy-2-phenylpyrimidine (44B) with no selectivity between them. 
Table 6. Microwave-assisted $\mathrm{Pd}\left(\mathrm{PPh}_{3}\right)_{4}$-catalyzed Suzuki coupling of aryl and heteroaryl boronic acids with $\mathbf{1}$.<smiles>Clc1ccnc(Cl)n1</smiles>

1

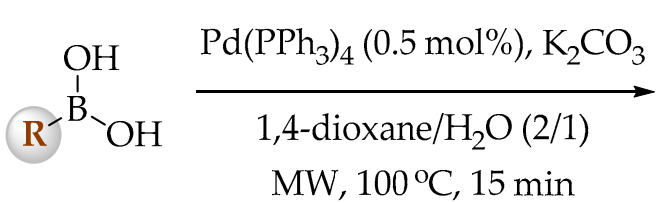

2, 5-18<smiles>Clc1nccc(Br)n1</smiles>

3, 26-39<smiles>Clc1nccc(-c2ccccc2)n1</smiles><smiles>COc1ccccc1-c1ccnc(Cl)n1</smiles><smiles>COc1cccc(-c2ccnc(Cl)n2)c1</smiles><smiles>COc1ccc(-c2ccnc(Cl)n2)cc1</smiles><smiles>Cc1cccc(-c2ccnc(Cl)n2)c1</smiles>

$3(79 \%)$ $26(76 \%)$ $27(72 \%)$ $28(77 \%)$

$29(75 \%)$<smiles>O=[N+]([O-])c1cccc(-c2ccnc(Cl)n2)c1</smiles><smiles>N#Cc1cccc(-c2ccnc(Cl)n2)c1</smiles><smiles>O=Cc1cccc(-c2ccnc(Cl)n2)c1</smiles><smiles>COC(=O)c1cccc(-c2ccnc(Cl)n2)c1</smiles><smiles>O=C(O)c1cccc(-c2ccnc(Cl)n2)c1</smiles><smiles>[13CH3]</smiles><smiles>[131In]</smiles>

$32(70 \%)$

$33(62 \%)$

34 (55\%)<smiles>Nc1cccc(-c2ccnc(Cl)n2)c1</smiles><smiles>Fc1ccc(-c2ccnc(Cl)n2)cc1</smiles><smiles>Clc1nccc(-c2ccc3ccccc3c2)n1</smiles><smiles>Clc1nccc(-c2ccco2)n1</smiles><smiles>Clc1nccc(-c2ccoc2)n1</smiles>

35 (55\%)

$36(62 \%)$

$37(87 \%)$

$38(50 \%)$

$39(66 \%)$

Reaction conditions: 1 (75 mg, $0.50 \mathrm{mmol})$, 1,4-dioxane $(4 \mathrm{~mL}), \mathrm{H}_{2} \mathrm{O}(2 \mathrm{~mL}), \mathrm{K}_{2} \mathrm{CO}_{3}(207 \mathrm{mg}, 1.50 \mathrm{mmol})$, boronic acid $(0.50 \mathrm{mmol}), \mathrm{Pd}\left(\mathrm{PPh}_{3}\right)_{4}(2.9 \mathrm{mg}, 0.0025 \mathrm{mmol}, 0.5 \mathrm{~mol} \%), \mathrm{MW}, 100{ }^{\circ} \mathrm{C}, 15 \mathrm{~min}$. Isolated yields after extraction and column chromatography are presented.

Taken together, the reaction is less susceptible to different substitutions on aryl boronic acids, with most of them giving high yield and selectivity at coupling with 2,4dichloropyrimidine. Since one of the major obstacles in coupling with heteroaryl chlorides is their potentially insufficient electron-deficiency, substitutions on the scaffold have immense effect on the outcome of Suzuki-Miyaura cross-coupling reactions. 
Table 7. Microwave-assisted $\mathrm{Pd}\left(\mathrm{PPh}_{3}\right)_{4}$-catalyzed Suzuki coupling of 2,4-dihalogenopyrimidines with 2.

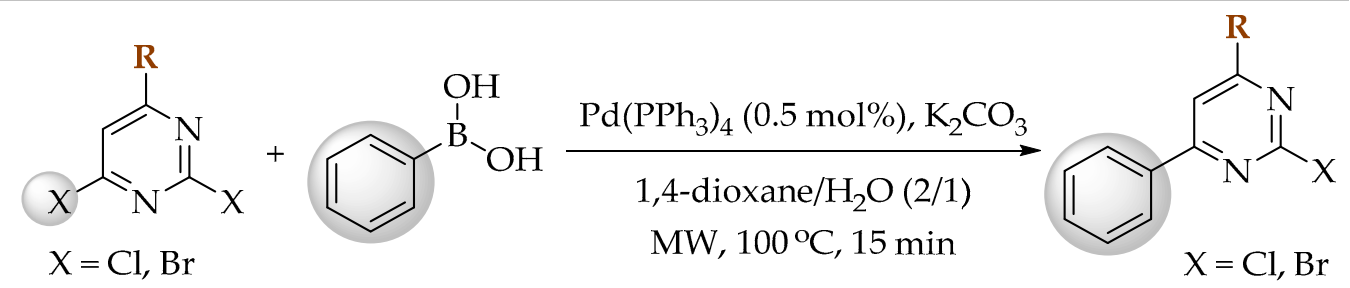

$1,19-25$

2

$3,40-46$<smiles>Clc1nccc(-c2ccccc2)n1</smiles>

$3(79 \%)$<smiles>Brc1nccc(-c2ccccc2)n1</smiles>

$40(48 \%)$<smiles>FC(F)(F)c1cc(-c2ccccc2)nc(Cl)n1</smiles>

$41(27 \%)$<smiles>O=C(O)c1cc(-c2ccccc2)nc(Cl)n1</smiles>

42 (92\%)<smiles>Cc1cc(-c2ccccc2)nc(Cl)n1</smiles>

43 (78\%)<smiles>COc1cc(-c2ccccc2)nc(Cl)n1</smiles>

44A (34\%)<smiles>COc1cc(Cl)nc(-c2ccccc2)n1</smiles>

44B (36\%)<smiles>Nc1cc(-c2ccccc2)nc(Cl)n1</smiles>

45 (84\%)<smiles>Clc1nc(-c2ccccc2)c2ccccc2n1</smiles>

46 (54\%)

Reaction conditions: 2,4-dihalogenopyrimidine (0.50 mmol), 1,4-dioxane (4 mL), $\mathrm{H}_{2} \mathrm{O}(2 \mathrm{~mL}), \mathrm{K}_{2} \mathrm{CO}_{3}(207 \mathrm{mg}$ $1.50 \mathrm{mmol}), 2(61 \mathrm{mg}, 0.50 \mathrm{mmol}), \mathrm{Pd}\left(\mathrm{PPh}_{3}\right)_{4}(2.9 \mathrm{mg}, 0.0025 \mathrm{mmol}, 0.5 \mathrm{~mol} \%), \mathrm{MW}, 100{ }^{\circ} \mathrm{C}, 15 \mathrm{~min}$. Isolated yields after extraction and column chromatography are presented.

\section{Materials and Methods}

\subsection{Chemistry and Chemical Characterization of Compounds}

The reagents and solvents were purchased from commercial sources (Sigma-Aldrich, St. Louis, MO, USA; Acros Organics, Antwerp, Belgium; Alfa Aesar, Haverhill, MA, USA; TCI, Tokio, Japan) and used without further purification. The microwave-assisted reactions were performed using an Anton Paar Monowave 200 microwave reactor (Anton Paar $\mathrm{GmbH}$, Graz, Austria). Flash column chromatography was performed on Merck silica gel 60 (mesh size, 70-230), using the indicated solvents. Monitoring of the purification was done by thin-layer chromatography on silica-gel plates (Merck DC Fertig-platten Kieselgel $60 \mathrm{GF}_{254}$, Merck, Darmstadt, Germany) and visualized under UV light. Yields refer to the purified products or were determined by LC-MS, as stated, and were not optimized. All of the melting points were determined on a Reichert hot-stage apparatus, and are uncorrected. ${ }^{1} \mathrm{H}$ and ${ }^{13} \mathrm{C} \mathrm{NMR}$ spectra were recorded at $295 \mathrm{~K}$ in $\mathrm{CDCl}_{3}$ or DMSO- $d_{6}$ on a Bruker Avance III NMR spectrometer equipped with a Broadband decoupling inverse ${ }^{1} \mathrm{H}$ probe. The coupling constants $(J)$ are in $\mathrm{Hz}$, and the splitting patterns are designated as: $s$, singlet; $d$, doublet; $d d$, double doublet; $t d$, triple doublet; $t$, triplet; $\mathrm{dt}$, double triplet; ddd, double of doublet of doublet; and m, multiplet. High-resolution mass measurements were performed on Exative ${ }^{\mathrm{TM}}$ Plus Orbitrap Mass Spectrometer (Thermo Fischer Scientific, Inc., Waltham, MA, USA). Monitoring of the reactions and determination of purities of the assayed compounds were done by Liquid Chromatography Mass Spectrometry (LCMS) on Agilent 1260 Infinity II LC System (Agilent Technologies, Santa Clara, CA, USA) equipped with quaternary pump and a variable wavelength detector, coupled to ADVION 
Expression CMSL Mass Spectrometer (Advion Inc., Ithaca, NY, USA). A Waters xBridge BEH C18 column was used $(4.6 \mathrm{~mm} \times 150 \mathrm{~mm}, 3.5 \mu \mathrm{m})$ at $40{ }^{\circ} \mathrm{C}$, with a flow rate of $1.5 \mathrm{~mL} / \mathrm{min}$, injection volume of $10 \mu \mathrm{L}$, detection at $254 \mathrm{~nm}$ and an eluent system of: $\mathrm{A}$, $1 \%$ of $\mathrm{CH}_{3} \mathrm{CN}$ and $0.1 \%$ of $\mathrm{HCOOH}$ in $\mathrm{ddH}_{2} \mathrm{O} ; \mathrm{B}, \mathrm{CH}_{3} \mathrm{CN}$. The following gradients were applied: $0-1 \mathrm{~min}, 25 \% \mathrm{~B} ; 1-6 \mathrm{~min}, 25 \% \rightarrow 98 \% \mathrm{~B} ; 6-6.5 \mathrm{~min}, 98 \% \mathrm{~B} ; 6.5-7 \mathrm{~min}, 98 \% \rightarrow 25 \%$ B; 7-10 min, 25\% B.

${ }^{1} \mathrm{H}$ and ${ }^{13} \mathrm{C}$ NMR spectra are available in the Supplementary Material related to this manuscript.

\subsection{General Procedure for Solvent Screening (Table 1)}

2,4-dichloropyrimidine 1 (149 $\mathrm{mg}, 1.0 \mathrm{mmol}$ ) was dissolved/ suspended in the selected solvent $(3.5 \mathrm{~mL})$, where the air (oxygen) was displaced with argon before use. Then potassium carbonate $\mathrm{K}_{2} \mathrm{CO}_{3}(415 \mathrm{mg}, 3.0 \mathrm{mmol})$, phenylboronic acid $2(122 \mathrm{mg}, 1.0 \mathrm{mmol})$, and $5 \mathrm{~mol} \%$ of tetrakis(triphenylphosphine)palladium $(0) \mathrm{Pd}\left(\mathrm{PPh}_{3}\right)_{4}(58 \mathrm{mg}, 0.05 \mathrm{mmol})$ were added and stirred under argon atmosphere at selected temperature (i.e., 60, 80, or $100^{\circ} \mathrm{C}$ ). After $24 \mathrm{~h}$, the reaction mixture was extracted with EtOAc, brine, and dried over anhydrous $\mathrm{Na}_{2} \mathrm{SO}_{4}$. Solvents were removed under reduced pressure, the remaining solid was purified using flash column chromatography with EtOAc/n-Hex as an eluent.

\subsection{General Procedure for Catalyst Screening (Table 2)}

$\mathbf{1}(75 \mathrm{mg}, 0.5 \mathrm{mmol})$ was dissolved in 1,4-dioxane $(3.5 \mathrm{~mL})$, where the air (oxygen) was displaced with argon before use. Then $\mathrm{K}_{2} \mathrm{CO}_{3}(207 \mathrm{mg}, 1.5 \mathrm{mmol}), 2(61 \mathrm{mg}, 0.5 \mathrm{mmol})$, and $5 \mathrm{~mol} \%$ of a selected catalyst $(0.05 \mathrm{mmol})$ with $10 \mathrm{~mol} \%$ of a ligand where applicable were added and stirred under argon atmosphere at $100{ }^{\circ} \mathrm{C}$.

$50 \mu \mathrm{L}$ of reaction mixture was diluted with $950 \mu \mathrm{L}$ of internal standard solution (prepared by $102 \mathrm{mg}$ of acetanilide in $100 \mathrm{~mL}$ of $\mathrm{CH}_{3} \mathrm{CN}$ ). The sample was further diluted (1/10) with $\mathrm{CH}_{3} \mathrm{CN}$ and filtered to obtain the final sample for LC-MS analysis.

In case of $\mathrm{Pd}(\mathrm{dppf}) \mathrm{Cl}_{2} \cdot \mathrm{CHCl}_{2}$ and $\mathrm{Pd}\left(\mathrm{PPh}_{3}\right)_{4}$ as catalyst, after $24 \mathrm{~h}$, the reaction mixture was extracted with EtOAc, brine and dried over anhydrous $\mathrm{Na}_{2} \mathrm{SO}_{4}$. Solvents were removed under reduced pressure, the remaining solid was purified using flash column chromatography with EtOAc/n-Hex as an eluent.

\subsection{General Procedure for Catalyst Screening-Use of Palladium on Multiwall Carbon Nanotubes}

$\mathbf{1}(75 \mathrm{mg}, 0.5 \mathrm{mmol})$ was dissolved in 1,4-dioxane $(3.5 \mathrm{~mL})$, where the air (oxygen) was displaced with argon before use. Then $\mathrm{K}_{2} \mathrm{CO}_{3}(207 \mathrm{mg}, 1.5 \mathrm{mmol}), 2(61 \mathrm{mg}, 0.5 \mathrm{mmol})$, and $0.2 \mathrm{~mol} \%$ of palladium on multiwall carbon nanotubes $(10.6 \mathrm{mg}, 0.11 \mathrm{mg}, 1.0 \mu \mathrm{M})$ was added and stirred under argon atmosphere at $100{ }^{\circ} \mathrm{C}$.

$50 \mu \mathrm{L}$ of reaction mixture was diluted with $950 \mu \mathrm{L}$ of internal standard solution (prepared by $102 \mathrm{mg}$ of acetanilide in $100 \mathrm{~mL}$ of $\mathrm{CH}_{3} \mathrm{CN}$ ). The sample was further diluted $(1 / 10)$ with $\mathrm{CH}_{3} \mathrm{CN}$ and filtered to obtain the final sample for LC-MS analysis.

\subsection{General Procedure for Solvent Mixture Screening (Table 3)}

$\mathbf{1}\left(75 \mathrm{mg}, 0.5 \mathrm{mmol}\right.$ ) was dissolved in a mixture of THF or 1,4-dioxane and $\mathrm{H}_{2} \mathrm{O}$ (total $6 \mathrm{~mL}$ ), where the air (oxygen) was displaced with argon before use. Then $\mathrm{K}_{2} \mathrm{CO}_{3}(207 \mathrm{mg}$, $1.5 \mathrm{mmol}), 2(61 \mathrm{mg}, 0.5 \mathrm{mmol})$, and $3 \mathrm{~mol} \%$ of $\mathrm{Pd}\left(\mathrm{PPh}_{3}\right)_{4}(17.3 \mathrm{mg}, 0.015 \mathrm{mmol})$ were added and stirred under argon atmosphere. The reaction mixture was then stirred for $20 \mathrm{~min}$ at $100{ }^{\circ} \mathrm{C}$ in a microwave reactor.

$50 \mu \mathrm{L}$ of reaction mixture was diluted with $950 \mu \mathrm{L}$ of internal standard solution (prepared by $102 \mathrm{mg}$ of acetanilide in $100 \mathrm{~mL}$ of $\mathrm{CH}_{3} \mathrm{CN}$ ). The sample was further diluted (1/10) with $\mathrm{CH}_{3} \mathrm{CN}$ and filtered to obtain the final sample for LC-MS analysis.

\subsection{General Procedure for Temperatuer and Time Screening (Table 4)}

$1(75 \mathrm{mg}, 0.5 \mathrm{mmol})$ was dissolved in a mixture of 1,4-dioxane $(4 \mathrm{~mL})$ and $\mathrm{H}_{2} \mathrm{O}$ $(2 \mathrm{~mL})$, where the air (oxygen) was displaced with argon before use. Then $\mathrm{K}_{2} \mathrm{CO}_{3}(207 \mathrm{mg}$, 
$1.5 \mathrm{mmol}), 2$ (61 mg, $0.5 \mathrm{mmol})$, and $3 \mathrm{~mol} \%$ of $\mathrm{Pd}\left(\mathrm{PPh}_{3}\right)_{4}(17.3 \mathrm{mg}, 0.015 \mathrm{mmol})$ were added and stirred under argon atmosphere. The reaction mixture was then stirred at several different temperatures (i.e., $60,80,100,120$, and $140{ }^{\circ} \mathrm{C}$ ) in a microwave reactor for a specified amount of time (i.e., 5, 10, 15, and $20 \mathrm{~min}$ ).

$50 \mu \mathrm{L}$ of reaction mixture was diluted with $950 \mu \mathrm{L}$ of internal standard solution (prepared by $102 \mathrm{mg}$ of acetanilide in $100 \mathrm{~mL}$ of $\mathrm{CH}_{3} \mathrm{CN}$ ). The sample was further diluted $(1 / 10)$ with $\mathrm{CH}_{3} \mathrm{CN}$ and filtered to obtain the final sample for LC-MS analysis.

\subsection{General Procedure for Catalyst Loading Screening (Table 5)}

$1(75 \mathrm{mg}, 0.5 \mathrm{mmol})$ was dissolved in a mixture of 1,4-dioxane $(4 \mathrm{~mL})$ and $\mathrm{H}_{2} \mathrm{O}$ $(2 \mathrm{~mL})$, where the air (oxygen) was displaced with argon before use. Then $\mathrm{K}_{2} \mathrm{CO}_{3}(207 \mathrm{mg}$, $1.5 \mathrm{mmol}), 2(61 \mathrm{mg}, 0.5 \mathrm{mmol})$, and appropriate amount of $\mathrm{Pd}\left(\mathrm{PPh}_{3}\right)_{4}$ (i.e., $0.05,0.2,0.5,1$, 2,3 , and $5 \mathrm{~mol} \%$ ) were added and stirred under argon atmosphere. The reaction mixture was then stirred for $15 \mathrm{~min}$ at $100{ }^{\circ} \mathrm{C}$ in a microwave reactor.

$50 \mu \mathrm{L}$ of reaction mixture was diluted with $950 \mu \mathrm{L}$ of internal standard solution (prepared by $102 \mathrm{mg}$ of acetanilide in $100 \mathrm{~mL}$ of $\mathrm{CH}_{3} \mathrm{CN}$ ). The sample was further diluted $(1 / 10)$ with $\mathrm{CH}_{3} \mathrm{CN}$ and filtered to obtain the final sample for LC-MS analysis.

\subsection{General Procedure for Scale-Up}

$1(600 \mathrm{mg}, 4.0 \mathrm{mmol})$ was dissolved in a mixture of 1,4-dioxane $(10 \mathrm{~mL})$ and $\mathrm{H}_{2} \mathrm{O}$ $(5 \mathrm{~mL})$, where the air (oxygen) was displaced with argon before use. Then $\mathrm{K}_{2} \mathrm{CO}_{3}(1.656 \mathrm{~g}$, $12.0 \mathrm{mmol}), 2$ (488 mg, $4.0 \mathrm{mmol})$, and $0.5 \mathrm{~mol} \%$ of $\mathrm{Pd}\left(\mathrm{PPh}_{3}\right)_{4}(23.12 \mathrm{mg}, 0.02 \mathrm{mmol})$ were added and stirred under argon atmosphere. The reaction mixture was then stirred for a specified amount of time (i.e., $15,20 \mathrm{~min}$ ) at $100{ }^{\circ} \mathrm{C}$ in a microwave reactor.

$50 \mu \mathrm{L}$ of reaction mixture was diluted with $950 \mu \mathrm{L}$ of internal standard solution (prepared by $102 \mathrm{mg}$ of acetanilide in $100 \mathrm{~mL}$ of $\mathrm{CH}_{3} \mathrm{CN}$ ). The sample was further diluted $(1 / 10)$ with $\mathrm{CH}_{3} \mathrm{CN}$ and filtered to obtain the final sample for LC-MS analysis.

\subsection{General Procedure for Screening of Boronic Acids (Table 6)}

$1(75 \mathrm{mg}, 0.5 \mathrm{mmol})$ was dissolved in a mixture of 1,4-dioxane $(4 \mathrm{~mL})$ and $\mathrm{H}_{2} \mathrm{O}$ $(2 \mathrm{~mL})$, where the air (oxygen) was displaced with argon before use. Then $\mathrm{K}_{2} \mathrm{CO}_{3}(207 \mathrm{mg}$, $1.5 \mathrm{mmol})$, appropriate boronic acid $(0.5 \mathrm{mmol})$, and $0.5 \mathrm{~mol} \%$ of $\mathrm{Pd}\left(\mathrm{PPh}_{3}\right)_{4}(2.9 \mathrm{mg}$, $0.0025 \mathrm{mmol}$ ) were added and stirred under argon atmosphere. The reaction mixture was then stirred for $15 \mathrm{~min}$ at $100{ }^{\circ} \mathrm{C}$ in a microwave reactor. Afterwards, reaction mixture was extracted with EtOAc, brine, and dried over anhydrous $\mathrm{Na}_{2} \mathrm{SO}_{4}$. Solvents were removed under reduced pressure, the remaining solid was purified using flash column chromatography with EtOAc/n-Hex as an eluent.

\subsection{General Procedure for Screening of 2,4-Dihalogenopyrimidines (Table 7)}

Appropriate 2,4-dihalogenopyrimidine $(0.5 \mathrm{mmol})$ was dissolved in a mixture of 1,4 dioxane ( $4 \mathrm{~mL})$ and $\mathrm{H}_{2} \mathrm{O}(2 \mathrm{~mL})$, where the air (oxygen) was displaced with argon before use. Then $\mathrm{K}_{2} \mathrm{CO}_{3}(207 \mathrm{mg}, 1.5 \mathrm{mmol}), 2(61 \mathrm{mg}, 0.5 \mathrm{mmol})$, and $0.5 \mathrm{~mol} \%$ of $\mathrm{Pd}\left(\mathrm{PPh}_{3}\right)_{4}$ $(2.9 \mathrm{mg}, 0.0025 \mathrm{mmol}$ ) were added and stirred under argon atmosphere. The reaction mixture was then stirred for $15 \mathrm{~min}$ at $100^{\circ} \mathrm{C}$ in a microwave reactor. Afterwards, reaction mixture was extracted with EtOAc, brine, and dried over anhydrous $\mathrm{Na}_{2} \mathrm{SO}_{4}$. Solvents were removed under reduced pressure, the remaining solid was purified using flash column chromatography with EtOAc/n-Hex as an eluent.

\subsection{Analytics of the Synthesized Compounds}

2-chloro-4-phenylpyrimidine (3): white solid, $\mathrm{Mp} 86-87^{\circ} \mathrm{C}$ (lit. 84-86 $\left.{ }^{\circ} \mathrm{C}[41]\right) ;{ }^{1} \mathrm{H}$ NMR $\left(400 \mathrm{MHz}, \mathrm{CDCl}_{3}\right): \delta(\mathrm{ppm})=7.48-7.54(\mathrm{~m}, 3 \mathrm{H}), 7.64(\mathrm{~d}, J=5.3 \mathrm{~Hz}, 1 \mathrm{H}), 8.07-8.10(\mathrm{~m}, 2 \mathrm{H})$, $8.63(\mathrm{~d}, J=5.3 \mathrm{~Hz}, 1 \mathrm{H}) ;{ }^{13} \mathrm{C} \mathrm{NMR}\left(100 \mathrm{MHz}, \mathrm{CDCl}_{3}\right): \delta(\mathrm{ppm})=115.27,127.55,129.25$, 132.04, 135.17, 159.95, 161.99, 167.30; HRMS (ESI+) $m / z$ calc. for $\mathrm{C}_{10} \mathrm{H}_{8} \mathrm{~N}_{2} \mathrm{Cl}[\mathrm{M}+\mathrm{H}]^{+}$ 191.0371, found 191.0369; HPLC $t_{R}=6.41 \mathrm{~min} ; \mathrm{Rf}=0.43(\mathrm{EtOAc} / \mathrm{n}-\mathrm{Hex}, 1: 2, v / v)$. 
4-chloro-2-phenylpyrimidine (4): white solid, $\mathrm{Mp} 72-73{ }^{\circ} \mathrm{C}$ (lit. 73-74 $\left.{ }^{\circ} \mathrm{C}[42]\right) ;{ }^{1} \mathrm{H}$ NMR $\left(400 \mathrm{MHz}, \mathrm{CDCl}_{3}\right): \delta(\mathrm{ppm})=7.23(\mathrm{~d}, J=5.2 \mathrm{~Hz}, 1 \mathrm{H}), 7.48-7.52(\mathrm{~m}, 3 \mathrm{H}), 8.43-8.46(\mathrm{~m}, 2 \mathrm{H})$, $8.67(\mathrm{~d}, J=5.2 \mathrm{~Hz}, 1 \mathrm{H}) ;{ }^{13} \mathrm{C}$ NMR $\left(100 \mathrm{MHz}, \mathrm{CDCl}_{3}\right): \delta(\mathrm{ppm})=119.45,128.66,128.81$, $131.68,136.23,158.39,161.70,165.71$; HRMS (ESI+) $m / z$ calc. for $\mathrm{C}_{10} \mathrm{H}_{8} \mathrm{~N}_{2} \mathrm{Cl}[\mathrm{M}+\mathrm{H}]^{+}$ 191.0371, found 191.0371; HPLC $t_{R}=7.09 \mathrm{~min} ; \mathrm{Rf}=0.55(\mathrm{EtOAc} / \mathrm{n}-\mathrm{Hex}, 1: 2, v / v)$.

2-chloro-4-(2-methoxyphenyl)pyrimidine (26): Yield: $76 \%$; white solid; $\mathrm{Mp} 53-54{ }^{\circ} \mathrm{C} ;{ }^{1} \mathrm{H}$ $\operatorname{NMR}\left(400 \mathrm{MHz}, \mathrm{CDCl}_{3}\right): \delta(\mathrm{ppm})=3.92(\mathrm{~s}, 3 \mathrm{H}), 7.00-7.04(\mathrm{~m}, 1 \mathrm{H}), 7.11\left(\mathrm{td}, J_{1}=1.1 \mathrm{~Hz}\right.$, $\mathrm{J} 2=7.6 \mathrm{~Hz}, 1 \mathrm{H}), 7.48(\mathrm{ddd}, \mathrm{J} 1=1.8 \mathrm{~Hz}, \mathrm{~J} 2=7.4 \mathrm{~Hz}, \mathrm{~J} 3=8.4 \mathrm{~Hz}, 1 \mathrm{H}), 7.97(\mathrm{~d}, \mathrm{~J}=5.3 \mathrm{~Hz}, 1 \mathrm{H})$, $8.09\left(\mathrm{dd}, J_{1}=1.8 \mathrm{~Hz}, J_{2}=7.8 \mathrm{~Hz}, 1 \mathrm{H}\right), 8.57(\mathrm{~d}, J=5.3 \mathrm{~Hz}, 1 \mathrm{H})$ as reported [43]; ${ }^{13} \mathrm{C} \mathrm{NMR}$ $\left(100 \mathrm{MHz}, \mathrm{CDCl}_{3}\right): \delta(\mathrm{ppm})=55.76,111.65,120.21,121.43,124.53,131.47,13.86,158.32$, 159.05, 161.31, 165.82; HRMS (ESI+) $\mathrm{m} / z$ calc. for $\mathrm{C}_{10} \mathrm{H}_{10} \mathrm{~N}_{2} \mathrm{OCl}[\mathrm{M}+\mathrm{H}]^{+} 221.0476$, found 221.0476; HPLC $t_{R}=6.41 \mathrm{~min} ; \mathrm{Rf}=0.36($ EtOAc $/ \mathrm{n}-\mathrm{Hex}, 1: 4, v / v)$.

2-chloro-4-(3-methoxyphenyl)pyrimidine (27): Yield: $72 \%$; white solid; $\mathrm{Mp} 68-70{ }^{\circ} \mathrm{C}$ (lit. $\left.83-86{ }^{\circ} \mathrm{C}[44]\right) ;{ }^{1} \mathrm{H} \mathrm{NMR}\left(400 \mathrm{MHz}, \mathrm{CDCl}_{3}\right): \delta(\mathrm{ppm})=3.90(\mathrm{~s}, 3 \mathrm{H}), 7.09\left(\mathrm{ddd}, J_{1}=0.9 \mathrm{~Hz}\right.$, $\left.J_{2}=2.6 \mathrm{~Hz}, J_{3}=8.2 \mathrm{~Hz}, 1 \mathrm{H}\right), 7.42(\mathrm{t}, J=8.0 \mathrm{~Hz}, 1 \mathrm{H}), 7.63(\mathrm{~d}, J=5.3 \mathrm{~Hz}, 1 \mathrm{H}), 7.61-7.67$ $(\mathrm{m}, 2 \mathrm{H}), 8.64(\mathrm{~d}, J=5.3 \mathrm{~Hz}, 1 \mathrm{H}) ;{ }^{13} \mathrm{C} \mathrm{NMR}\left(100 \mathrm{MHz}, \mathrm{CDCl}_{3}\right): \delta(\mathrm{ppm})=55.67,112.61$, $115.48,118.06,119.92,130.29,136.64,159.97,160.41,161.99,167.17$; HRMS (ESI+) $\mathrm{m} / z$ calc. for $\mathrm{C}_{10} \mathrm{H}_{10} \mathrm{~N}_{2} \mathrm{OCl}[\mathrm{M}+\mathrm{H}]^{+}$221.0476, found 221.0476; HPLC $t_{R}=6.34 \mathrm{~min} ; \mathrm{Rf}=0.24$ (EtOAc/n-Hex, 1:4, v/v).

2-chloro-4-(4-methoxyphenyl)pyrimidine (28): Yield: 77\%; white solid; Mp 106-108 ${ }^{\circ} \mathrm{C}$ (lit. $\left.137-140{ }^{\circ} \mathrm{C}[44]\right) ;{ }^{1} \mathrm{H}$ NMR $\left(400 \mathrm{MHz}, \mathrm{CDCl}_{3}\right): \delta(\mathrm{ppm})=3.89(\mathrm{~s}, 3 \mathrm{H}), 6.99-7.03(\mathrm{~m}, 2 \mathrm{H})$, $7.57(\mathrm{~d}, J=5.3 \mathrm{~Hz}, 1 \mathrm{H}), 8.06-8.10(\mathrm{~m}, 2 \mathrm{H}), 8.56(\mathrm{~d}, J=5.3 \mathrm{~Hz}, 1 \mathrm{H}) ;{ }^{13} \mathrm{C} \mathrm{NMR}(100 \mathrm{MHz}$, $\left.\mathrm{CDCl}_{3}\right): \delta(\mathrm{ppm})=55.65,114.32,114.63,127.57,129.30,159.58,161.90,162.96,166.79 ;$ HRMS $(\mathrm{ESI}+) \mathrm{m} / \mathrm{z}$ calc. for $\mathrm{C}_{11} \mathrm{H}_{10} \mathrm{ON}_{2} \mathrm{Cl}[\mathrm{M}+\mathrm{H}]^{+} 221.0476$, found 221.0476; HPLC $t_{R}=6.30 \mathrm{~min}$; $\mathrm{Rf}=0.18($ EtOAc/n-Hex, 1:4, v/v).

2-chloro-4-(m-tolyl)pyrimidine (29): Yield: $75 \%$; white solid; $\mathrm{Mp} 74-75{ }^{\circ} \mathrm{C} ;{ }^{1} \mathrm{H}$ NMR $\left(400 \mathrm{MHz}, \mathrm{CDCl}_{3}\right): \delta(\mathrm{ppm})=2.45(\mathrm{~s}, 3 \mathrm{H}), 7.34-7.38(\mathrm{~m}, 1 \mathrm{H}), 7.40(\mathrm{t}, J=7.5 \mathrm{~Hz}, 1 \mathrm{H}), 7.64$ $(\mathrm{d}, J=5.3 \mathrm{~Hz}, 1 \mathrm{H}), 7.84-7.87(\mathrm{~m}, 1 \mathrm{H}), 7.92-7.94(\mathrm{~m}, 1 \mathrm{H}), 8.62(\mathrm{~d}, J=5.3 \mathrm{~Hz}, 1 \mathrm{H}) ;{ }^{13} \mathrm{C}$ NMR $\left(100 \mathrm{MHz}, \mathrm{CDCl}_{3}\right): \delta(\mathrm{ppm})=21.59,115.38,124.72,128.18,129.16,132.87,135.18,139.16$, 159.88, 161.98, 167.56; HRMS (ESI+) $\mathrm{m} / z$ calc. for $\mathrm{C}_{11} \mathrm{H}_{10} \mathrm{~N}_{2} \mathrm{Cl}[\mathrm{M}+\mathrm{H}]^{+}$205.0527, found 205.0529; HPLC $t_{R}=6.87 \mathrm{~min} ; \mathrm{Rf}=0.35(\mathrm{EtOAc} / \mathrm{n}-\mathrm{Hex}, 1: 3, v / v)$.

2-chloro-4-(3-nitrophenyl)pyrimidine (30): Yield: 79\%; yellow solid; Mp $123-125{ }^{\circ} \mathrm{C} ;{ }^{1} \mathrm{H}$ $\operatorname{NMR}\left(400 \mathrm{MHz}, \mathrm{CDCl}_{3}\right): \delta(\mathrm{ppm})=7.74(\mathrm{t}, J=8.0 \mathrm{~Hz}, 1 \mathrm{H}), 7.76(\mathrm{~d}, J=5.2 \mathrm{~Hz}, 1 \mathrm{H}), 8.41$ $\left(\mathrm{ddd}, J_{1}=1.1 \mathrm{~Hz}, J_{2}=2.2 \mathrm{~Hz}, J_{3}=8.2 \mathrm{~Hz}, 1 \mathrm{H}\right), 8.48\left(\mathrm{ddd}, J_{1}=1.1 \mathrm{~Hz}, J_{2}=1.8 \mathrm{~Hz}, J_{3}=7.8 \mathrm{~Hz}\right.$, $1 \mathrm{H}), 8.76(\mathrm{~d}, J=5.2 \mathrm{~Hz}, 1 \mathrm{H}), 8.93(\mathrm{t}, J=1.9 \mathrm{~Hz}, 2 \mathrm{H})$ as reported $[45] ;{ }^{13} \mathrm{C} \mathrm{NMR}(100 \mathrm{MHz}$, $\left.\mathrm{CDCl}_{3}\right): \delta(\mathrm{ppm})=115.46,122.46,126.40,130.48,133.26,136.96,149.01,160.77,162.37$, 164.64; HRMS (ESI+) $m / z$ calc. for $\mathrm{C}_{10} \mathrm{H}_{7} \mathrm{O}_{2} \mathrm{~N}_{3} \mathrm{Cl}[\mathrm{M}+\mathrm{H}]^{+}$236.0221, found 236.0221; HPLC $t_{R}=6.33 \mathrm{~min} ; \mathrm{Rf}=0.17($ EtOAc $/ \mathrm{n}-\mathrm{Hex}, 1: 2, v / v)$.

3-(2-chloropyrimidin-4-yl)benzonitrile (31): Yield: $83 \%$; pale pink solid; Mp $180-182{ }^{\circ} \mathrm{C}$; ${ }^{1} \mathrm{H} \mathrm{NMR}\left(400 \mathrm{MHz}, \mathrm{CDCl}_{3}\right): \delta(\mathrm{ppm})=7.64-7.68(\mathrm{~m}, 1 \mathrm{H}), 7.68(\mathrm{~d}, J=5.2 \mathrm{~Hz}, 1 \mathrm{H}), 7.83$ $\left(\mathrm{dt}, J_{1}=1.4 \mathrm{~Hz}, J_{2}=7.7 \mathrm{~Hz}, 1 \mathrm{H}\right), 8.33\left(\mathrm{ddd}, J_{1}=1.2 \mathrm{~Hz}, J_{2}=1.9 \mathrm{~Hz}, J_{3}=8.0 \mathrm{~Hz}, 1 \mathrm{H}\right)$, $8.41(\mathrm{t}, J=1.8 \mathrm{~Hz}, 1 \mathrm{H}), 8.74(\mathrm{~d}, J=5.2 \mathrm{~Hz}, 1 \mathrm{H})$ as reported [46]; ${ }^{13} \mathrm{C}$ NMR $(100 \mathrm{MHz}$, $\left.\mathrm{CDCl}_{3}\right): \delta(\mathrm{ppm})=113.84,115.31,118.10,130.23,131.18,131.56,135.00,136.47,160.70$, 162.34, 164.79; HRMS (ESI+) $m / z$ calc. for $\mathrm{C}_{11} \mathrm{H}_{7} \mathrm{~N}_{3} \mathrm{Cl}[\mathrm{M}+\mathrm{H}]^{+}$216.0323, found 216.0323; HPLC $t_{R}=5.97 \mathrm{~min} ; \mathrm{Rf}=0.17($ EtOAc/n-Hex, $1: 2, v / v)$.

3-(2-chloropyrimidin-4-yl)benzaldehyde (32): Yield: 70\%; white solid; Mp $120-122{ }^{\circ} \mathrm{C} ;{ }^{1} \mathrm{H}$ $\operatorname{NMR}\left(400 \mathrm{MHz}, \mathrm{CDCl}_{3}\right): \delta(\mathrm{ppm})=7.70(\mathrm{t}, J=7.7 \mathrm{~Hz}, 1 \mathrm{H}), 7.74(\mathrm{~d}, J=5.3 \mathrm{~Hz}, 1 \mathrm{H}), 8.05(\mathrm{dt}$, $\left.J_{1}=1.4 \mathrm{~Hz}, J_{2}=7.6 \mathrm{~Hz}, 1 \mathrm{H}\right), 8.38\left(\mathrm{dt}, J_{1}=1.5 \mathrm{~Hz}, J_{2}=7.7 \mathrm{~Hz}, 1 \mathrm{H}\right), 8.58(\mathrm{t}, J=1.8 \mathrm{~Hz}, 1 \mathrm{H})$, $8.71(\mathrm{~d}, J=5.1 \mathrm{~Hz}, 1 \mathrm{H}), 10.12(\mathrm{~s}, 1 \mathrm{H}) ;{ }^{13} \mathrm{C} \mathrm{NMR}\left(100 \mathrm{MHz}, \mathrm{CDCl}_{3}\right): \delta(\mathrm{ppm})=115.40,128.63$, $130.11,132.71,133.13,136.22,137.19,160.45,162.17,165.78,191.58$; HRMS (ESI+) $m / z$ calc. for $\mathrm{C}_{11} \mathrm{H}_{8} \mathrm{ON} \mathrm{ON}_{2} \mathrm{Cl}[\mathrm{M}+\mathrm{H}]^{+} 219.0320$, found 219.0322 as reported [47]; HPLC $t_{R}=5.61 \mathrm{~min}$; $\mathrm{Rf}=0.32($ EtOAc/n-Hex, 1:1, v/v).

Methyl 3-(2-chloropyrimidin-4-yl)benzoate (33): Yield: $62 \%$; white solid; $\mathrm{Mp} 108-110{ }^{\circ} \mathrm{C}$; ${ }^{1} \mathrm{H} \mathrm{NMR}\left(400 \mathrm{MHz}, \mathrm{CDCl}_{3}\right): \delta(\mathrm{ppm})=3.97(\mathrm{~s}, 3 \mathrm{H}), 7.61(\mathrm{t}, J=7.8 \mathrm{~Hz}, 1 \mathrm{H}), 7.72(\mathrm{~d}, J=5.3 \mathrm{~Hz}$, 
$1 \mathrm{H}), 8.20\left(\mathrm{dt}, J_{1}=1.4 \mathrm{~Hz}, J_{2}=7.8 \mathrm{~Hz}, 1 \mathrm{H}\right), 8.34\left(\mathrm{ddd}, J_{1}=1.2 \mathrm{~Hz}, J_{2}=1.9 \mathrm{~Hz}, J_{3}=7.9 \mathrm{~Hz}, 1 \mathrm{H}\right)$, $8.68(\mathrm{~d}, J=5.3 \mathrm{~Hz}, 1 \mathrm{H}), 8.69-8.70(\mathrm{~m}, 1 \mathrm{H})$ as reported $[48] ;{ }^{13} \mathrm{C} \mathrm{NMR}\left(100 \mathrm{MHz}, \mathrm{CDCl}_{3}\right): \delta$ $(\mathrm{ppm})=52.58,115.42,128.57,129.52,131.30,131.88,132.86,135.61,160.28,162.13,166.24$, 166.43; HRMS (ESI+) $m / z$ calc. for $\mathrm{C}_{12} \mathrm{H}_{10} \mathrm{O}_{2} \mathrm{~N}_{2} \mathrm{Cl}[\mathrm{M}+\mathrm{H}]^{+}$249.0425, found 249.0424; HPLC $t_{R}=6.29 \mathrm{~min} ; \mathrm{Rf}=0.25(\mathrm{EtOAc} / \mathrm{n}-\mathrm{Hex}, 1: 2, v / v)$.

3-(2-chloropyrimidin-4-yl)benzoic acid (34): Yield: 55\%; white solid; Mp $196-198{ }^{\circ} \mathrm{C} ;{ }^{1} \mathrm{H}$ NMR $\left(400 \mathrm{MHz}, \mathrm{DMSO}-d_{6}\right): \delta(\mathrm{ppm})=7.49(\mathrm{t}, J=7.7 \mathrm{~Hz}, 1 \mathrm{H}), 8.12-8.16(\mathrm{~m}, 3 \mathrm{H}), 8.72-8.74$ $(\mathrm{m}, 1 \mathrm{H}), 8.76(\mathrm{~d}, J=5.3 \mathrm{~Hz}, 1 \mathrm{H}), 1 \mathrm{H}$ from $\mathrm{COOH}$ is exchanged as reported [47]; ${ }^{13} \mathrm{C} \mathrm{NMR}$ $\left(100 \mathrm{MHz}, \mathrm{DMSO}-d_{6}\right): \delta(\mathrm{ppm})=116.07,128.19,128.28,132.80,133.70,140.01,160.51,161.08$, 166.51, 169.84; HRMS (ESI-) $m / z$ calc. for $\mathrm{C}_{11} \mathrm{H}_{6} \mathrm{O}_{2} \mathrm{~N}_{2} \mathrm{Cl}[\mathrm{M}-\mathrm{H}]^{-}$233.0123, found 233.0122; $\mathrm{HPLC} t_{R}=4.96 \mathrm{~min} ; \mathrm{Rf}=0.14(\mathrm{DCM} / \mathrm{MeOH}, 9: 1, v / v)$.

3-(2-chloropyrimidin-4-yl)aniline (35): Yield: 55\%; yellow solid; Mp 120-122 ${ }^{\circ} \mathrm{C}$ (lit. 137-138 $\left.{ }^{\circ} \mathrm{C}[49]\right) ;{ }^{1} \mathrm{H}$ NMR $\left(400 \mathrm{MHz} \mathrm{CDCl}_{3}\right): \delta(\mathrm{ppm})=3.86(\mathrm{~s}, 2 \mathrm{H}), 6.85\left(\mathrm{ddd}, J_{1}=1.0 \mathrm{~Hz}\right.$, $\left.J_{2}=2.4 \mathrm{~Hz}, J_{3}=7.9 \mathrm{~Hz}, 1 \mathrm{H}\right), 7.28(\mathrm{t}, J=7.9 \mathrm{~Hz}, 1 \mathrm{H}), 7.38\left(\mathrm{ddd}, J_{1}=1.0 \mathrm{~Hz}, J_{2}=1.8 \mathrm{~Hz}\right.$, $\left.J_{3}=7.9 \mathrm{~Hz}, 1 \mathrm{H}\right), 7.48(\mathrm{t}, J=2.0 \mathrm{~Hz}, 1 \mathrm{H}), 7.60(\mathrm{~d}, J=5.3 \mathrm{~Hz}, 1 \mathrm{H}), 8.61(\mathrm{~d}, J=5.3 \mathrm{~Hz}, 1 \mathrm{H}) ;{ }^{13} \mathrm{C}$ $\operatorname{NMR}\left(100 \mathrm{MHz}, \mathrm{CDCl}_{3}\right): \delta(\mathrm{ppm})=113.67,115.41,117.61,118.60,130.15,136.21,147.37$, 159.83, 161.86, 167.51; HRMS (ESI+) $m / z$ calc. for $\mathrm{C}_{10} \mathrm{H}_{9} \mathrm{~N}_{3} \mathrm{Cl}[\mathrm{M}+\mathrm{H}]^{+} 206.0480$, found 206.0478; HPLC $t_{R}=3.35 \mathrm{~min} ; \mathrm{Rf}=0.23($ EtOAc/n-Hex, 1:1, v/v).

2-chloro-4-(4-fluorophenyl)pyrimidine (36): Yield: $62 \%$; white solid; Mp $101-103{ }^{\circ} \mathrm{C} ;{ }^{1} \mathrm{H}$ $\operatorname{NMR}\left(400 \mathrm{MHz}, \mathrm{CDCl}_{3}\right): \delta(\mathrm{ppm})=7.18-7.24(\mathrm{~m}, 2 \mathrm{H}), 7.61(\mathrm{~d}, J=5.3 \mathrm{~Hz}, 1 \mathrm{H}), 8.10-8.15$ $(\mathrm{m}, 2 \mathrm{H}), 8.64(\mathrm{~d}, J=5.3 \mathrm{~Hz}, 1 \mathrm{H}) ;{ }^{13} \mathrm{C} \mathrm{NMR}\left(100 \mathrm{MHz}, \mathrm{CDCl}_{3}\right): \delta(\mathrm{ppm})=114.91,116.47(\mathrm{~d}$, $\left.J_{C-F}=22.0 \mathrm{~Hz}\right), 129.82\left(\mathrm{~d}, J_{C-F}=8.9 \mathrm{~Hz}\right), 131.37,160.06,162.07,162.25\left(\mathrm{~d}, J_{C-F}=253.3 \mathrm{~Hz}\right)$, 166.62; HRMS (ESI+) $m / z$ calc. for $\mathrm{C}_{10} \mathrm{H}_{7} \mathrm{~N}_{2} \mathrm{ClF}[\mathrm{M}+\mathrm{H}]^{+}$209.0276, found 209.0278; HPLC $t_{R}=6.44 \mathrm{~min} ; \mathrm{Rf}=0.31($ EtOAc $/ \mathrm{n}-\mathrm{Hex}, 1: 3, v / v)$.

2-chloro-4-(naphthalen-2-yl)pyrimidine (37): Yield: 87\%; white solid; Mp $114-116{ }^{\circ} \mathrm{C} ;{ }^{1} \mathrm{H}$ $\mathrm{NMR}\left(400 \mathrm{MHz}, \mathrm{CDCl}_{3}\right): \delta(\mathrm{ppm})=7.54-7.62(\mathrm{~m}, 2 \mathrm{H}), 7.79(\mathrm{~d}, J=5.3 \mathrm{~Hz}, 1 \mathrm{H}), 7.88-7.92$ $(\mathrm{m}, 1 \mathrm{H}), 7.95-8.01(\mathrm{~m}, 2 \mathrm{H}), 8.15\left(\mathrm{dd}, J_{1}=1.9 \mathrm{~Hz}, J_{2}=8.6 \mathrm{~Hz}, 1 \mathrm{H}\right), 8.65-8.67(\mathrm{~m}, 1 \mathrm{H}), 8.68(\mathrm{~d}$, $J=5.3 \mathrm{~Hz}, 1 \mathrm{H}) ;{ }^{13} \mathrm{C} \mathrm{NMR}\left(100 \mathrm{MHz}, \mathrm{CDCl}_{3}\right): \delta(\mathrm{ppm})=115.49,123.78,127.08,127.95,128.19$, $128.40,129.17,129.38,132.42,133.26,135.17,160.01,162.10,167.27$; HRMS (ESI+) $m / z$ calc. for $\mathrm{C}_{14} \mathrm{H}_{10} \mathrm{~N}_{2} \mathrm{Cl}[\mathrm{M}+\mathrm{H}]^{+} 241.0527$, found 241.0528 as reported [50]; HPLC $t_{R}=7.31 \mathrm{~min}$; $\mathrm{Rf}=0.28($ EtOAc/n-Hex, 1:3, v/v).

2-chloro-4-(furan-2-yl)pyrimidine (38): Yield: 50\%; white solid; Mp $67-69{ }^{\circ} \mathrm{C} ;{ }^{1} \mathrm{H} \mathrm{NMR}$ $\left(400 \mathrm{MHz}, \mathrm{CDCl}_{3}\right): \delta(\mathrm{ppm})=6.61\left(\mathrm{dd}, J_{1}=1.7 \mathrm{~Hz}, J_{2}=3.5 \mathrm{~Hz}, 1 \mathrm{H}\right), 7.39\left(\mathrm{dd}, J_{1}=0.7 \mathrm{~Hz}\right.$, $\left.J_{2}=3.5 \mathrm{~Hz}, 1 \mathrm{H}\right), 7.53(\mathrm{~d}, J=5.2 \mathrm{~Hz}, 1 \mathrm{H}), 7.63\left(\mathrm{dd}, J_{1}=0.7 \mathrm{~Hz}, J_{2}=1.7 \mathrm{~Hz}, 1 \mathrm{H}\right), 8.58(\mathrm{~d}$, $J=5.2 \mathrm{~Hz}, 1 \mathrm{H})$ as reported $[51] ;{ }^{13} \mathrm{C} \mathrm{NMR}\left(100 \mathrm{MHz}, \mathrm{CDCl}_{3}\right): \delta(\mathrm{ppm})=113.10,113.13$, $114.58,146.24,150.52,158.11,159.92,161.76 ; \mathrm{HRMS}(\mathrm{ESI}+) \mathrm{m} / z$ calc. for $\mathrm{C}_{8} \mathrm{H}_{6} \mathrm{ON}_{2} \mathrm{Cl}[\mathrm{M}+$ $\mathrm{H}]^{+}$181.0163, found 181.0163; HPLC $t_{R}=5.03 \mathrm{~min} ; \mathrm{Rf}=0.27($ EtOAc $/ \mathrm{n}-\mathrm{Hex} ; 1: 4, v / v)$.

2-chloro-4-(furan-3-yl)pyrimidine (39): Yield: 66\%; grey solid; Mp 62-64 ${ }^{\circ} \mathrm{C}$ (lit. 87$\left.89{ }^{\circ} \mathrm{C}[52]\right) ;{ }^{1} \mathrm{H} \mathrm{NMR}\left(400 \mathrm{MHz}, \mathrm{CDCl}_{3}\right): \delta(\mathrm{ppm})=6.90\left(\mathrm{dd}, J_{1}=0.9 \mathrm{~Hz}, J_{2}=1.9 \mathrm{~Hz}, 1 \mathrm{H}\right)$, $7.32(\mathrm{~d}, J=5.1 \mathrm{~Hz}, 1 \mathrm{H}), 7.52-7.55(\mathrm{~m}, 1 \mathrm{H}), 8.21-8.23(\mathrm{~m}, 1 \mathrm{H}), 8.55(\mathrm{~d}, J=5.2 \mathrm{~Hz}, 1 \mathrm{H}) ;{ }^{13} \mathrm{C}$ $\operatorname{NMR}\left(100 \mathrm{MHz}, \mathrm{CDCl}_{3}\right): \delta(\mathrm{ppm})=108.36,115.06,124.41,144.77,144.88,159.67,161.91$, 161.98; HRMS (ESI+) $m / z$ calc. for $\mathrm{C}_{8} \mathrm{H}_{6} \mathrm{ON}_{2} \mathrm{Cl}[\mathrm{M}+\mathrm{H}]^{+}$181.0163, found 181.0161; HPLC $t_{R}=5.29 \mathrm{~min} ; \mathrm{Rf}=0.18($ EtOAc $/ \mathrm{n}-\mathrm{Hex}, 1: 4, v / v)$.

2-bromo-4-phenylpyrimidine (40): Yield: $48 \%$; white solid; Mp $68-70{ }^{\circ} \mathrm{C}$ (lit. 85-87 ${ }^{\circ} \mathrm{C}$ [20]; ${ }^{1} \mathrm{H} \mathrm{NMR}\left(400 \mathrm{MHz} \mathrm{CDCl}_{3}\right): \delta(\mathrm{ppm})=7.49-7.55(\mathrm{~m}, 3 \mathrm{H}), 7.69(\mathrm{~d}, J=5.3 \mathrm{~Hz}, 1 \mathrm{H}), 8.07-8.10$ $(\mathrm{m}, 2 \mathrm{H}), 8.57(\mathrm{~d}, J=5.3 \mathrm{~Hz}, 1 \mathrm{H}) ;{ }^{13} \mathrm{C} \mathrm{NMR}\left(100 \mathrm{MHz}, \mathrm{CDCl}_{3}\right): \delta(\mathrm{ppm})=115.67,127.58$, $129.28,132.08,135.13,153.79,159.73,167.13$; HRMS (ESI+) $m / z$ calc. for $\mathrm{C}_{10} \mathrm{H}_{7} \mathrm{BrN}_{2}[\mathrm{M}+$ $\mathrm{H}]^{+}$234.9865, found 234.9869; HPLC $t_{R}=6.45 \mathrm{~min} ; \mathrm{Rf}=0.38($ EtOAc $/ \mathrm{n}-\mathrm{Hex}, 1: 2, v / v)$.

2-chloro-4-phenyl-6-(trifluoromethyl)pyrimidine (41): Yield: 27\%; pale yellow solid; Mp 47-49 ${ }^{\circ} \mathrm{C} ;{ }^{1} \mathrm{H}$ NMR $\left(400 \mathrm{MHz}, \mathrm{CDCl}_{3}\right): \delta(\mathrm{ppm})=7.54-7.63(\mathrm{~m}, 3 \mathrm{H}), 7.96(\mathrm{~s}, 1 \mathrm{H}), 8.15-8.18$ $(\mathrm{m}, 2 \mathrm{H}) ;{ }^{13} \mathrm{C} \mathrm{NMR}\left(100 \mathrm{MHz}, \mathrm{CDCl}_{3}\right): \delta(\mathrm{ppm})=100.13,111.06,120.08\left(\mathrm{q}, J_{\mathrm{C}-\mathrm{F}}=274.1 \mathrm{~Hz}\right)$, $127.93,129.55,133.14,133.78,134.25,169.84 ; \mathrm{HRMS}(\mathrm{ESI}+) \mathrm{m} / z$ calc. for $\mathrm{C}_{11} \mathrm{H}_{7} \mathrm{~N}_{2} \mathrm{ClF}_{3}[\mathrm{M}+$ $\mathrm{H}]^{+}$259.0244, found 259.0250; HPLC $t_{R}=7.51 \mathrm{~min} ; \mathrm{Rf}=0.60(\mathrm{EtOAc} / \mathrm{n}-\mathrm{Hex}, 1: 4, v / v)$. 
2-chloro-6-phenylpyrimidine-4-carboxylic acid (42): Yield: $92 \%$; appearance; $\mathrm{Mp}>300{ }^{\circ} \mathrm{C}$; ${ }^{1} \mathrm{H}$ NMR $\left(400 \mathrm{MHz}\right.$, DMSO- $\left.d_{6}\right): \delta(\mathrm{ppm})=7.51-7.58(\mathrm{~m}, 3 \mathrm{H}), 8.13-8.16(\mathrm{~m}, 2 \mathrm{H}), 8.29(\mathrm{~s}, 1 \mathrm{H})$, $1 \mathrm{H}$ from $\mathrm{COOH}$ is exchanged; ${ }^{13} \mathrm{C}$ NMR $\left(100 \mathrm{MHz}, \mathrm{DMSO}-d_{6}\right): \delta(\mathrm{ppm})=114.06,127.24$, $129.17,131.80,134.90,160.30,165.40,166.62,168.53$; HRMS (ESI-) $m / z$ calc. for $\mathrm{C}_{11} \mathrm{H}_{6} \mathrm{O}_{2} \mathrm{~N}_{2} \mathrm{Cl}$ $[\mathrm{M}-\mathrm{H}]^{-}$233.0123, found 233.0121; HPLC $t_{R}=5.29 \mathrm{~min} ; \mathrm{Rf}=0.04(\mathrm{DCM} / \mathrm{MeOH}, 9: 1, v / v)$

2-chloro-4-methyl-6-phenylpyrimidine (43): Yield: 78\%; pale orange solid; $\mathrm{Mp} 42-44{ }^{\circ} \mathrm{C}$; ${ }^{1} \mathrm{H} \mathrm{NMR}\left(400 \mathrm{MHz}, \mathrm{CDCl}_{3}\right): \delta(\mathrm{ppm})=2.60(\mathrm{~s}, 3 \mathrm{H}), 7.48-7.55(\mathrm{~m}, 4 \mathrm{H}), 8.06-8.08(\mathrm{~m}, 2 \mathrm{H})$ as reported [53]; ${ }^{13} \mathrm{C} \mathrm{NMR}\left(100 \mathrm{MHz}, \mathrm{CDCl}_{3}\right): \delta(\mathrm{ppm})=24.37,100.13,114.87,127.55,129.19$, 131.75, 135.49, 166.96, 170.98; HRMS (ESI+) $m / z$ calc. for $\mathrm{C}_{11} \mathrm{H}_{10} \mathrm{~N}_{2} \mathrm{Cl}[\mathrm{M}+\mathrm{H}]^{+}$205.0527, found 205.0528; HPLC $t_{R}=6.60 \mathrm{~min} ; \mathrm{Rf}=0.41(\mathrm{EtOAc} / \mathrm{n}-\mathrm{Hex}, 1: 2, v / v)$.

2-chloro-4-methoxy-6-phenylpyrimidine (44A): Yield: $34 \%$; white solid; $\mathrm{Mp} 88-90{ }^{\circ} \mathrm{C} ;{ }^{1} \mathrm{H}$ $\operatorname{NMR}\left(400 \mathrm{MHz}, \mathrm{CDCl}_{3}\right): \delta(\mathrm{ppm})=4.05(\mathrm{~s}, 3 \mathrm{H}), 7.03(\mathrm{~s}, 1 \mathrm{H}), 7.47-7.51(\mathrm{~m}, 3 \mathrm{H}), 8.00-8.03$ $(\mathrm{m}, 2 \mathrm{H}) ;{ }^{13} \mathrm{C} \mathrm{NMR}\left(100 \mathrm{MHz} \mathrm{CDCl}_{3}\right): \delta(\mathrm{ppm})=54.87,102.05,127.36,129.06,131.38,135.62$, 160.45, 167.10, 171.87; HRMS (ESI+) $m / z$ calc. for $\mathrm{C}_{11} \mathrm{H}_{10} \mathrm{ON}_{2} \mathrm{Cl}[\mathrm{M}+\mathrm{H}]^{+}$221.0476, found 221.0477; HPLC $t_{R}=7.41 \mathrm{~min} ; \mathrm{Rf}=0.62(\mathrm{EtOAc} / \mathrm{n}-\mathrm{Hex}, 1: 2, v / v)$.

4-chloro-6-methoxy-2-phenylpyrimidine (44B): Yield: $36 \%$; white solid; $\mathrm{Mp} 49-51{ }^{\circ} \mathrm{C} ;{ }^{1} \mathrm{H}$ $\operatorname{NMR}\left(400 \mathrm{MHz}, \mathrm{CDCl}_{3}\right): \delta(\mathrm{ppm})=4.11(\mathrm{~s}, 3 \mathrm{H}), 6.66(\mathrm{~s}, 1 \mathrm{H}), 7.47-7.54(\mathrm{~m}, 3 \mathrm{H}), 8.42-8.46$ $(\mathrm{m}, 2 \mathrm{H}) ;{ }^{13} \mathrm{C}$ NMR $\left(100 \mathrm{MHz}, \mathrm{CDCl}_{3}\right): \delta(\mathrm{ppm})=54.44,105.24,128.62,128.67,131.59,136.35$, 161.10, 164.79, 170.77; HRMS (ESI+) $\mathrm{m} / \mathrm{z}$ calc. for $\mathrm{C}_{11} \mathrm{H}_{10} \mathrm{ON}_{2} \mathrm{Cl}[\mathrm{M}+\mathrm{H}]^{+}$221.0476, found 221.0475; HPLC $t_{R}=7.96 \mathrm{~min} ; \mathrm{Rf}=0.65($ EtOAc $/ \mathrm{n}-\mathrm{Hex}, 1: 2, v / v)$.

2-chloro-6-phenylpyrimidin-4-amine (45): Yield: 84\%; pale yellow solid; Mp $160-162{ }^{\circ} \mathrm{C}$; ${ }^{1} \mathrm{H}$ NMR $(400 \mathrm{MHz}, \mathrm{CDCl} 3): \delta(\mathrm{ppm})=5.39(\mathrm{~s}, 2 \mathrm{H}), 6.72(\mathrm{~s}, 1 \mathrm{H}), 7.44-7.48(\mathrm{~m}, 3 \mathrm{H}), 7.94-7.96$ $(\mathrm{m}, 2 \mathrm{H}) ;{ }^{13} \mathrm{C} \mathrm{NMR}\left(100 \mathrm{MHz}, \mathrm{CDCl}_{3}\right): \delta(\mathrm{ppm})=98.87,127.20,128.94,131.05,136.12,161.13$, 165.10, 166.03; HRMS (ESI+) $m / z$ calc. for $\mathrm{C}_{10} \mathrm{H}_{9} \mathrm{~N}_{3} \mathrm{Cl}[\mathrm{M}+\mathrm{H}]^{+}$206.0480, found 206.0477; HPLC $t_{R}=5.25 \mathrm{~min} ; \mathrm{Rf}=0.43($ EtOAc $/ \mathrm{n}-\mathrm{Hex}, 1: 1, v / v)$.

2-chloro-4-phenylquinazoline (46): Yield: $54 \%$; white solid; Mp 91-92 ${ }^{\circ} \mathrm{C}$ (lit. 112 $\left.114{ }^{\circ} \mathrm{C}[41]\right) ;{ }^{1} \mathrm{H}$ NMR $\left(400 \mathrm{MHz}, \mathrm{DMSO}-d_{6}\right): \delta(\mathrm{ppm})=7.56-7.61(\mathrm{~m}, 3 \mathrm{H}), 7.63(\mathrm{ddd}$, $\left.J_{1}=1.2 \mathrm{~Hz}, J_{2}=6.9 \mathrm{~Hz}, J_{3}=8.3 \mathrm{~Hz}, 1 \mathrm{H}\right), 7.77-7.82(\mathrm{~m}, 2 \mathrm{H}), 7.95\left(\mathrm{ddd}, J_{1}=1.4 \mathrm{~Hz}, J_{2}=6.9 \mathrm{~Hz}\right.$, $\left.J_{3}=8.4 \mathrm{~Hz}, 1 \mathrm{H}\right), 8.06\left(\mathrm{ddd}, J_{1}=0.7 \mathrm{~Hz}, J_{2}=1.2 \mathrm{~Hz}, J_{3}=8.5 \mathrm{~Hz}, 1 \mathrm{H}\right), 8.14\left(\mathrm{ddd}, J_{1}=0.7 \mathrm{~Hz}\right.$, $\left.J_{2}=1.4 \mathrm{~Hz}, J_{3}=8.4 \mathrm{~Hz}, 1 \mathrm{H}\right) ;{ }^{13} \mathrm{C}$ NMR $\left(100 \mathrm{MHz}, \mathrm{DMSO}-d_{6}\right): \delta(\mathrm{ppm})=121.76,127.64$, $128.14,128.26,128.90,130.28,130.84,135.02,136.04,153.16,157.18,171.84 ;$ HRMS (ESI+) $\mathrm{m} / \mathrm{z}$ calc. for $\mathrm{C}_{14} \mathrm{H}_{10} \mathrm{~N}_{2} \mathrm{Cl}[\mathrm{M}+\mathrm{H}]^{+} 241.0527$, found 241.0523; HPLC $t_{R}=7.08 \mathrm{~min} ; \mathrm{Rf}=0.29$ $($ EtOAc/n-Hex, 1:5, v/v).

\section{Conclusions}

Substituted pyrimidine rings represent an attractive scaffold, which has been often present in compounds with diverse biological activities. One of the most straightforward routes for preparation of substituted pyrimidines are cross-coupling reactions with Suzuki coupling being among them. In the present study we developed a quick, efficient, and regioselective procedure for preparation of C4-substituted pyrimidines from commercially available 2,4-dichloropyrimidines. A thorough screening of reaction conditions was performed, with the microwave-assisted 15-min protocol offering regioselective C4-pyrimidine substitution in good to high yields. Additionally, with only $0.5 \mathrm{~mol} \%$ consumption of tetrakis(triphenylphosphine)palladium(0) catalyst, the environmental impact of the reaction is negligible. The scope of the reaction was investigated on several aryl and heteroaryl boronic acids and substituted 2,4-dihalogenopyrimidines, with most of them being readily amenable for Suzuki-Miyaura coupling. We believe that our microwave-assisted procedure bears significant potential for the rapid preparation of regioselective C4-substituted pyrimidines with high yields and most importantly extremely low catalyst loading.

Supplementary Materials: The following are available online at https: / www.mdpi.com/article/ 10.3390/catal11040439/s1, Additional description of procedure optimization (Solvent screening, Temperature screening, Screening of the solvent volume for microwave-assisted Suzuki coupling between 1 and 2); ${ }^{1} \mathrm{H}$ NMR and ${ }^{13} \mathrm{C}$ NMR spectra of compounds. 
Author Contributions: Conceptualization, A.D. and M.S.; methodology, A.D., K.M., and M.S.; validation, A.D. and K.M.; formal analysis, A.D. and K.M.; investigation, A.D., K.M., and M.S..; resources, M.S.; data curation, A.D. and M.S.; writing-original draft preparation, A.D. and M.S.; writingreview and editing, A.D. and M.S.; visualization, M.S.; supervision, M.S.; project administration, M.S.; funding acquisition, A.D. and M.S. All authors have read and agreed to the published version of the manuscript.

Funding: This research was funded by Slovenian Research Agency (research core funding No. P1-0208 and junior researcher's programme for Ana Dolšak).

Conflicts of Interest: The authors declare no conflict of interest.

\section{References}

1. Chiacchio, M.A.; Iannazzo, D.; Romeo, R.; Giofrè, S.V.; Legnani, L. Pyridine and pyrimidine derivatives as privileged scaffolds in biologically active agents. Curr. Med. Chem. 2019, 26, 7166-7195. [CrossRef]

2. Kumar, S.; Narasimhan, B. Therapeutic potential of heterocyclic pyrimidine scaffolds. Chem. Cent. J. 2018, 12, 38. [CrossRef]

3. Lagoja, I.M. Pyrimidine as constituent of natural biologically active compounds. Chem. Biodivers. 2005, 2, 1-50. [CrossRef] [PubMed]

4. Kumar, S.; Deep, A.; Narasimhan, B. A review on synthesis, anticancer and antiviral potentials of pyrimidine derivatives. Curr. Bioact. Compd. 2019, 15, 289-303. [CrossRef]

5. MacCoss, M.; Robins, M.J. Anticancer pyrimidines, pyrimidine nucleosides and prodrugs. In The Chemistry of Antitumour Agents; Wilman, D.E.V., Ed.; Springer: Dordrecht, The Netherlands, 1990; pp. 261-298. ISBN 978-94-009-0397-5.

6. Manley, P.W.; Cowan-Jacob, S.W.; Buchdunger, E.; Fabbro, D.; Fendrich, G.; Furet, P.; Meyer, T.; Zimmermann, J. Imatinib: A selective tyrosine kinase inhibitor. Eur. J. Cancer 2002, 38, S19-S27. [CrossRef]

7. Langtry, H.D.; Campoli-Richards, D.M. Zidovudine. A review of its pharmacodynamic and pharmacokinetic properties, and therapeutic efficacy. Drugs 1989, 37, 408-450. [CrossRef] [PubMed]

8. Brogden, R.N.; Carmine, A.A.; Heel, R.C.; Speight, T.M.; Avery, G.S. Trimethoprim: A review of its antibacterial activity, pharmacokinetics and therapeutic use in urinary tract infections. Drugs 1982, 23, 405-430. [CrossRef] [PubMed]

9. White, C.M. A review of the pharmacologic and pharmacokinetic aspects of rosuvastatin. J. Clin. Pharmacol. 2002, 42, 963-970. [CrossRef]

10. Sica, D.A. Minoxidil: An underused vasodilator for resistant or severe hypertension. J. Clin. Hypertens. 2004, 6, 283-287. [CrossRef] [PubMed]

11. Gore, R.P.; Rajput, A.P. A review on recent progress in multicomponent reactions of pyrimidine synthesis. Drug Invent Today 2013, 5, 148-152. [CrossRef]

12. Mahfoudh, M.; Abderrahim, R.; Leclerc, E.; Campagne, J.-M. Recent approaches to the synthesis of pyrimidine derivatives. Eur. J. Org. Chem. 2017, 2017, 2856-2865. [CrossRef]

13. Maji, P.K. Recent progress in the synthesis of pyrimidine heterocycles: A review. Curr. Org. Chem. 2020, 24, 1055-1096. [CrossRef]

14. Roopan, S.M.; Sompalle, R. Synthetic chemistry of pyrimidines and fused pyrimidines: A review. Synth. Commun. 2016, 46, 645-672. [CrossRef]

15. Eicher, T.; Hauptmann, S.; Speicher, A. Six-Membered Heterocycles: Sections 6.25-6.31. In The Chemistry of Heterocycles; John Wiley \& Sons, Ltd.: Hoboken, NJ, USA, 2003; pp. 381-416. ISBN 978-3-527-60183-7.

16. Joule, J.A.; Mills, K. Heterocyclic Chemistry, 5th ed.; Wiley-Blackwell: Hoboken, NJ, USA, 2010; ISBN 978-1-4051-3300-5.

17. Parks, E.L.; Sandford, G.; Christopher, J.A.; Miller, D.D. Perhalogenated pyrimidine scaffolds. Reactions of 5-chloro-2,4,6trifluoropyrimidine with nitrogen centred nucleophiles. Beilstein J. Org. Chem. 2008, 4, 22. [CrossRef]

18. Carver, D.R.; Komin, A.P.; Hubbard, J.S.; Wolfe, J.F. SRN1 mechanism in heteroaromatic nucleophilic substitution. reactions involving halogenated pyrimidines, pyridazines, and pyrazines. J. Org. Chem. 1981, 46, 294-299. [CrossRef]

19. Delia, T.J. Grignard reactions involving halogenated pyrimidines. J. Heterocycl. Chem. 2013, 50, 735-745. [CrossRef]

20. Schomaker, J.M.; Delia, T.J. Arylation of halogenated pyrimidines via a Suzuki coupling reaction. J. Org. Chem. 2001, 66, 7125-7128. [CrossRef]

21. Anderson, S.C.; Handy, S.T. One-pot double Suzuki couplings of dichloropyrimidines. Synthesis 2010, 2010, 2721-2724. [CrossRef]

22. Schröter, S.; Stock, C.; Bach, T. Regioselective cross-coupling reactions of multiple halogenated nitrogen-, oxygen-, and sulfurcontaining heterocycles. Tetrahedron 2005, 61, 2245-2267. [CrossRef]

23. Large, J.M.; Clarke, M.; Williamson, D.M.; McDonald, E.; Collins, I. Synthesis of trisubstituted pyrimidines by regioselective SNAr and Suzuki reactions of polyhalopyrimidines. Synlett 2006, 2006, 861-864. [CrossRef]

24. Almond-Thynne, J.; Blakemore, D.C.; Pryde, D.C.; Spivey, A.C. Site-selective Suzuki-Miyaura coupling of heteroaryl halidesUnderstanding the trends for pharmaceutically important classes. Chem. Sci. 2016, 8, 40-62. [CrossRef] [PubMed]

25. Benneche, T.; Oscarson, S.; Kvarnström, I.; Niklasson, A.; Niklasson, G.; Svensson, S.C.T.; Edwards, J.V. Pyrimidinylpalladium(II) complexes in the synthesis of alkenylpyrimidines. Acta Chem. Scand. 1990, 44, 927-931. [CrossRef]

26. Tan, J.; Chang, J.; Deng, M. The facile route to stereodefined alkenyl-substituted pyrimidines. Synth. Commun. 2004, 34, 3773-3783. [CrossRef] 
27. CRESTOR ${ }^{\circledR}$ (Rosuvastatin Calcium) Prescribing Information I AZ Medical Information. Available online: https: / / medicalinformation. astrazeneca-us.com/home/prescribing-information/crestor-pi.html (accessed on 1 December 2020).

28. McMullin, C.L.; Fey, N.; Harvey, J.N. Computed ligand effects on the oxidative addition of phenyl halides to phosphine supported palladium(0) catalysts. Dalton Trans. 2014, 43, 13545-13556. [CrossRef] [PubMed]

29. Yaman, T.; Harvey, J.N. Suzuki-Miyaura coupling revisited: An integrated computational study. Faraday Discuss. 2019, 220, 425-442. [CrossRef] [PubMed]

30. Miyaura, N.; Suzuki, A. Palladium-catalyzed cross-coupling reactions of organoboron compounds. Chem. Rev. 1995, 95, 2457-2483. [CrossRef]

31. Sherwood, J.; Clark, J.H.; Fairlamb, I.J.S.; Slattery, J.M. Solvent effects in palladium catalysed cross-coupling reactions. Green Chem. 2019, 21, 2164-2213. [CrossRef]

32. Liu, N.; Liu, C.; Jin, Z. An efficient protocol for a $\mathrm{Pd}(\mathrm{OAc})_{2}$-catalyzed ligand-free Suzuki reaction in toluene. Chin. J. Catal. 2010, 31, 1316-1320. [CrossRef]

33. Sun, J.; Jin, Z.; Xie, N.; Wang, H.; Gao, H. Studies on Suzuki coupling reactions of large sterically hindered substrates. Top. Chem. Mater. Eng. 2018, 1, 24-26. [CrossRef]

34. Adrio, L.A.; Nguyen, B.N.; Guilera, G.; Livingston, A.G.; Hii, K.K. Speciation of Pd(OAac) 2 in ligandless Suzuki-Miyaura reactions. Catal. Sci. Technol. 2012, 2, 316-323. [CrossRef]

35. Bhattacharyya, S.; Basu, B. Solid-Supported Catalysis. In Green Techniques for Organic Synthesis and Medicinal Chemistry; John Wiley \& Sons, Ltd.: Hoboken, NJ, USA, 2018; pp. 269-289. ISBN 978-1-119-28815-2.

36. Yakukhnov, S.A.; Pentsak, E.O.; Galkin, K.I.; Mironenko, R.M.; Drozdov, V.A.; Likholobov, V.A.; Ananikov, V.P. Rapid “mix-andstir" preparation of well-defined palladium on carbon catalysts for efficient practical use. ChemCatChem 2018, 10, 1869-1873. [CrossRef]

37. Trzeciak, A.M.; Wojcik, P.; Lisiecki, R.; Gerasymchuk, Y.; Strek, W.; Legendziewicz, J. Palladium nanoparticles supported on graphene oxide as catalysts for the synthesis of diarylketones. Catalysts 2019, 9, 319. [CrossRef]

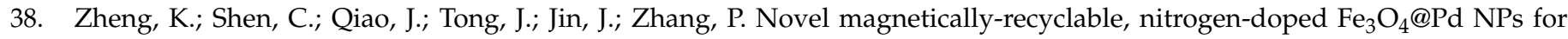
Suzuki-Miyaura coupling and their application in the synthesis of Crizotinib. Catalysts 2018, 8, 443. [CrossRef]

39. Blakemore, D. Chapter 1: Suzuki-Miyaura coupling. In Synthetic Methods in Drug Discovery: Volume 1; The Royal Society of Chemistry: London, UK, 2015; pp. 1-69.

40. Gravil, P.A.; Toulhoat, H. Hydrogen, sulphur and chlorine coadsorption on Pd(111): A theoretical study of poisoning and promotion. Surf. Sci. 1999, 430, 176-191. [CrossRef]

41. Harden, D.B.; Mokrosz, M.J.; Strekowski, L. Addition and substitution reactions of chloropyrimidines with lithium reagents. J. Org. Chem. 1988, 53, 4137-4140. [CrossRef]

42. Plas, H.C.V.D.; Haase, B.; Zuurdeeg, B.; Vollering, M.C. Ring transformations in reactions of heterocyclic halogeno compounds with nucleophiles (V): Conversion of some 2-alkyl-, 2-aryl- and 2,5-dialkyl-4-chloropyrimidines by potassium amide in liquid ammonia into 4-alkyl derivatives of 2-alkyl- or 2-aryl-s-triazines. Recl. Trav. Chim. Pays-Bas 1966, 85, 1101-1113. [CrossRef]

43. Czudor, Z.; Balogh, M.; Bánhegyi, P.; Boros, S.; Breza, N.; Dobos, J.; Fábián, M.; Horváth, Z.; Illyés, E.; Markó, P.; et al. Novel compounds with potent CDK9 inhibitory activity for the treatment of myeloma. Bioorg. Med. Chem. Lett. 2018, 28, 769-773. [CrossRef]

44. Cuccia, S.J.; Fleming, L.B.; France, D.J. A novel and efficient synthesis of 4-phenyl-2-chloropyrimidines from acetophenone cyanoimines. Synth. Commun. 2002, 32, 3011-3018. [CrossRef]

45. Shu, L.; Chen, C.; Huan, X.; Huang, H.; Wang, M.; Zhang, J.; Yan, Y.; Liu, J.; Zhang, T.; Zhang, D. Design, synthesis, and pharmacological evaluation of 4- or 6-phenyl-pyrimidine derivatives as novel and selective Janus kinase 3 inhibitors. Eur. J. Med. Chem. 2020, 191, 112148. [CrossRef]

46. Kemp, M.I.; Luckhurst, C.A.; Thompson, P.W. Substituted Cyanopyrrolidines with Activity as Usp30 Inhibitors. WO 2020/212351 A1, 14 April 2020.

47. William, A.D.; Lee, A.C.-H.; Blanchard, S.; Poulsen, A.; Teo, E.L.; Nagaraj, H.; Tan, E.; Chen, D.; Williams, M.; Sun, E.T.; et al. Discovery of the macrocycle 11-(2-pyrrolidin-1-yl-ethoxy)-14,19-dioxa-5,7,26-triaza-tetracyclo[1 9.3.1.1(2,6).1(8,12)] heptacosa1(25),2(26),3,5,8,10,12(27),16,21,23-decaene (SB1518), a potent Janus kinase 2/fms-like tyrosine kinase-3 (JAK2/FLT3) inhibitor for the treatment of myelofibrosis and lymphoma. J. Med. Chem. 2011, 54, 4638-4658. [CrossRef] [PubMed]

48. Ganesamoorthy, S.; Muthu Tamizh, M.; Shanmugasundaram, K.; Karvembu, R. A sustainable heterogenized palladium catalyst for Suzuki-Miyaura cross coupling reaction of azaheteroaryl halides in aqueous media. J. Organomet. Chem. 2018, 862, 76-85. [CrossRef]

49. Stanetty, P.; Röhrling, J.; Schnürch, M.; Mihovilovic, M.D. Synthesis of analogs of the phenylamino-pyrimidine type protein kinase C inhibitor CGP 60474 utilizing a Negishi cross-coupling strategy. Tetrahedron 2006, 62, 2380-2387. [CrossRef]

50. Pelletier, J.C.; Lundquist, J.T.; Gilbert, A.M.; Alon, N.; Bex, F.J.; Bhat, B.M.; Bursavich, M.G.; Coleburn, V.E.; Felix, L.A.; Green, D.M.; et al. (1-(4-(Naphthalen-2-yl)pyrimidin-2-yl)piperidin-4-yl)methanamine: A wingless $\beta$-catenin agonist that increases bone formation rate. J. Med. Chem. 2009, 52, 6962-6965. [CrossRef] [PubMed]

51. Bello, A.M.; Bende, T.; Wei, L.; Wang, X.; Majchrzak-Kita, B.; Fish, E.N.; Kotra, L.P. De novo design of nonpeptidic compounds targeting the interactions between interferon- $\alpha$ and its cognate cell surface receptor. J. Med. Chem. 2008, 51, 2734-2743. [CrossRef] [PubMed] 
52. Strekowski, L.; Harden, D.B.; Grubb, W.B.; Patterson, S.E.; Czarny, A.; Mokrosz, M.J.; Cegla, M.T.; Wydra, R.L. Synthesis of 2-chloro-4,6-di(heteroaryl)pyrimidines. J. Heterocycl. Chem. 1990, 27, 1393-1400. [CrossRef]

53. Kamal, R.; Kumar, R.; Kumar, V.; Kumar, V.; Bansal, K.K.; Sharma, P.C. Synthesis, anthelmintic and antimicrobial evaluation of new 2-arylidene-1-(4-methyl-6-phenylpyrimidin-2-yl)hydrazines. ChemistrySelect 2019, 4, 713-717. [CrossRef] 